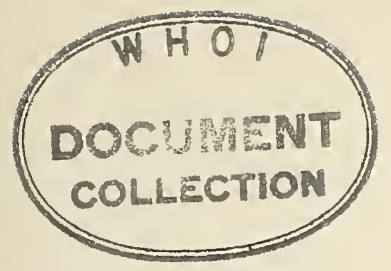

R681

Technical Report

$\mathrm{b}$
$\mathrm{b}$
$\mathrm{b}$
$\mathrm{b}$
$\mathrm{b}$

May 1970

Sponsored by

NAVAL FACILITIES ENGINEERING COMMAND

NAVAL CIVIL ENGINEERING LABORATORY

Port Hueneme, California

This document has been approved for public release and sale; its distribution is unlimited. 


\title{
RELATIONSHIP BETWEEN MARINE FOULING AND CORROSION RATE OF CARBON STEEL AND ALUMINUM ALLOY AT THE SURFACE AND AT 6,000-FOOT DEPTH
}

\author{
Technical Report R-681
}

YF 51.543.007.01.001

by

J. S. Muraoka

\section{ABSTRACT}

Carbon steel (1010) and aluminum alloy (7178-T6) panels were exposed at the surface (23 to 286 days) and at 6,000-foot depth (189 days) in the Pacific Ocean (1) to determine the effects of fouling organisms on the corrosion rate and (2) to compare the biological corrosion rate of identical test panels submerged at the two depths. Seawater samples obtained at the surface and at depth were analyzed for dissolved oxygen concentration, $\mathrm{pH}$, salinity and temperature. Bacteriological tests were also conducted on seawater samples. The test panels were submerged in the sea as follows to obtain data on corrosion rates: (1) enclosed inside an initially sterile plastic cylindrical chamber with both ends sealed with membrane filters (control panels), (2) placed inside a cylinder covered with 210-mesh nylon screen cloth, (3) placed inside a cylinder with both ends uncovered, and (4) attached to a phenolic plastic strip (exposed panels). The control specimens became contaminated; however, from corrosion data obtained on test panels exposed on the seafloor in 6,000 feet of water, it is concluded that slime films played a significant role in accelerating corrosion of test specimens. Test panels exposed at the surface corroded at faster rates than replicate test panels which were exposed on the seafloor in 6,000 feet of water. The corrosion rates of both steel and aluminum alloy panels approach constancy after extended exposure in the sea. The various environmental factors and their effects on the corrosion rates at the surface of the sea and at great depth on the seafloor are discussed.

\footnotetext{
This document has been approved for public release and sale; its distribution is unlimited. 


\section{CONTENTS}

page

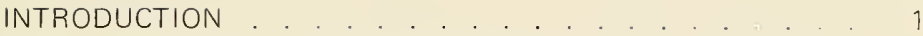

MATERIALS AND EXPERIMENTAL METHODS . . . . . 2

Preparation of Test Specimens . . . . . . . . . . 2

Design of Plastic Test Chambers . . . . . . . . . 3

Design of Plastic-Exposure Strips . . . . . . . . . 5

Sterilization of Test Chambers . . . . . . . . . 5

Shallow-Water Exposure Site . . . . . . . . . . 5

Analysis of Seawater . . . . . . . . . . 10

Chemical Tests . . . . . . . . . . . 10

Bacteriological Tests . . . . . . . . . 11

Evaluation of Test Specimens . . . . . . . . . 12

RESULTS AND DISCUSSION . . . . . . . . . . 12

Shallow Water Tests . . . . . . . . . . . 12

Exposure Test No. 1 (70, 112, and 268 Days) . . . . 12

Exposure Test No. 2 (64 and 92 Days). . . . . . . 25

Exposure Test No. 3 (23 and 43 Days). . . . . . . . 32

Deep-Ocean Exposure Test . . . . . . . . . . . . 42

Corrosion Rates-Surface Versus Deep Ocean . . . . . . . 49

FINDINGS AND CONCLUSIONS . . . . . . . . . . . 50

FUTURE PLANS . . . . . . . . . . . . . . . 50

REFERENCES . . . . . . . . . . . . . . . . 51 



\section{INTRODUCTION}

Corrosion is the deterioration of materials through chemical and electrochemical attack. It is a very complex form of material deterioration. Despite intensive research and experimentation, ${ }^{\mathbf{1 , 2}}$ there is a lot to learn about corrosion processes of metals and metal alloys submerged in the sea. Corrosion in the hostile hydrospace environment will continue to be a problem of major importance to marine engineers and designers.

When materials are submerged in the sea, the submerged object soon becomes covered with marine growth. ${ }^{3}$ LaQue and Clapp ${ }^{4}$ have found that certain species of marine organisms accelerate corrosion. The attachment of marine organisms on the surface of metals and metal alloys could be an important contributing factor in the complex corrosion process by producing local changes in dissolved oxygen concentration, $\mathrm{pH}$, and oxidation-reduction potential. For example, pitting occurs under barnacle shells as a result of a difference in oxygen concentration, ${ }^{5,6}$ and sulfate-reducing bacteria associated with anaerobic corrosion 7,8 are known to produce hydrogen sulfide under (1) corrosion products formed over metal surfaces, (2) deteriorating paint film, and (3) decaying organisms. Various species of microorganisms are also found to be responsible for the corrosion of metals and metal alloys in the marine environment. ${ }^{9,10}$

In order to study the importance of fouling organisms and their effects on corrosion rates of metals, an experimental method must be devised whereby the control panels exposed in the sea will be free of marine growth during the exposure period. The corrosion rate of the fouling-free test panels could then be compared to test panels which were exposed to maximum marine growth in the sea.

Himmelfarb and others ${ }^{11}$ have conducted a short-term ( $i$-week) marine exposure study to determine the effects of bacterial slime growth on corrosion of aluminum and copper. The control panels were kept free of any bacterial slime growth by placing the test panel inside a plastic dish filled with sterile distilled water and sealed with a 0.45 -micron porosity membrane filter. Reference 11 states that a sterile condition can be maintained inside the plastic dish and that seawater will quickly replace the distilled water by diffusion through the membrane filter. 
Presented in this report are the results of a long-term marine exposure study which was conducted to determine the effects of marine fouling on the corrosion rate of 1010 carbon steel and 7178-T6 aluminum alloy. The test panels were exposed at the surface of the sea and also on the seafloor in 6,000 feet of water. To compare the corrosion rates between fouling-free panels and heavily fouled panels, the fouling-free or control panels were placed inside a specially designed initially sterile cylindrical test chamber sealed with 0.45 -micron porosity membrane filters. For maximum fouling effects, the unprotected or exposed panels were secured to plastic strips and exposed to the seawater environment. Other test panels were exposed at the surface of the sea by placing them inside plastic cylinders with ends covered with a fine mesh plastic screen and also inside cylinders with ends left uncovered. The latter two tests were conducted primarily to determine the effects of tidal currents on corrosion and to compare the corrosion rates with exposed panels. The latter panels would all be subjected to attachment by various marine fouling organisms and to the effects of other marine environmental factors.

Seawater samples were collected from inside recovered test chambers sealed with membrane filters and analyzed for dissolved oxygen concentration, $\mathrm{pH}$, salinity and water temperature. Seawater samples from 10 feet below the surface of the sea (at high tide) and also from 6,000 feet below the surface of the sea were collected and similarly analyzed. Bacteriological analyses were also conducted on these seawater samples. The information about the seawater environment in which the test panels were exposed is essential in evaluating corrosion of metals and metal alloys.

For exposure of test specimens on the seafloor in 6,000 feet of water, the specimens were placed on a Submersible Test Unit (STU) and it was emplaced on the deep-ocean floor in the Pacific Ocean for a period of 189 days (6.3 months).

\section{MATERIALS AND EXPERIMENTAL METHODS}

\section{Preparation of Test Specimens}

The test specimens used in this study were made of 1010 carbon steel and 7178-T6 aluminum alloy and measured $1 / 8 \times 1 \times 3$ inches. Some 6-inchlong specimens were also used. A 1/4-inch-diameter hole was drilled at each end of the panels for assembly purposes. The test panels were treated as follows before exposure in the sea: 
1. The carbon steel panels were cleaned in an ultrasonically vibrated tank containing $10 \%$, by weight, ammonium citrate solution heated to $150^{\circ} \mathrm{F}$. The panels were then washed in hot running water, scrubbed with a fiber bristle brush, washed in hot running water, dipped into distilled water, rinsed in absolute ethyl alcohol, and then dried in a current of warm air.

2. The aluminum alloy panels were cleaned in an ultrasonically vibrated tank containing concentrated nitric acid at room temperature, and then washed, scrubbed, rinsed, and dried similarly to carbon steels.

3. The cleaned panels were weighed, measured, and stored in a room in which the relative humidity was maintained at $20 \%$.

4. Prior to assembly and placement inside test chambers, the test panels were sterilized by dipping in ethyl alcohol. These were assembled together $(2$ to 4 panels) by inserting nylon rods through the holes located at both ends of the test panels. The metal panels were kept apart with short pieces of vinyl tubing placed between the test panels over the nylon rod to prevent galvanic corrosion.

\section{Design of Plastic Test Chambers}

As shown in Figure 1, the test chambers were made from a 1/4-inchthick, 4-inch diameter, clear, transparent acrylic plastic tubing cut into 2 -inch lengths. A 1-inch diameter hole was drilled through the cylinder wall and it was plugged with a rubber stopper (water samples were obtained through this hole). The open ends of the cylinders were treated in different ways as follows:

1. Covered with 0.45 -micron porosity membrane filters. The thin filters were sandwiched in between two 210-mesh (0.0083-inch) nylon screen cloths to prevent rupture. These were in turn placed between two plastic end plates (Figure 1) and cemented together around the edges with a silicone adhesive. The test panels were then secured inside the cylinder with these end plates using machine screws. A silicone adhesive was used around the edges to serve as a sealant and gasket to prevent leaks. The test chamber was specially designed to facilitate continuous free exchange of seawater only through the membrane filter. After the sterilized test panels were aseptically placed inside the test chamber and both ends sealed with membrane filters, the chamber was filled with seawater by either submerging it in the sea or by placing the test chamber in a plastic container filled with filtered seawater. From laboratory tests, it was found that it takes about 30 minutes to fill a $350-\mathrm{ml}$ volume test chamber (without a rubber stopper) with seawater flowing through the membrane filter; also from laboratory tests, the dissolved oxygen concentration, salinity, and 


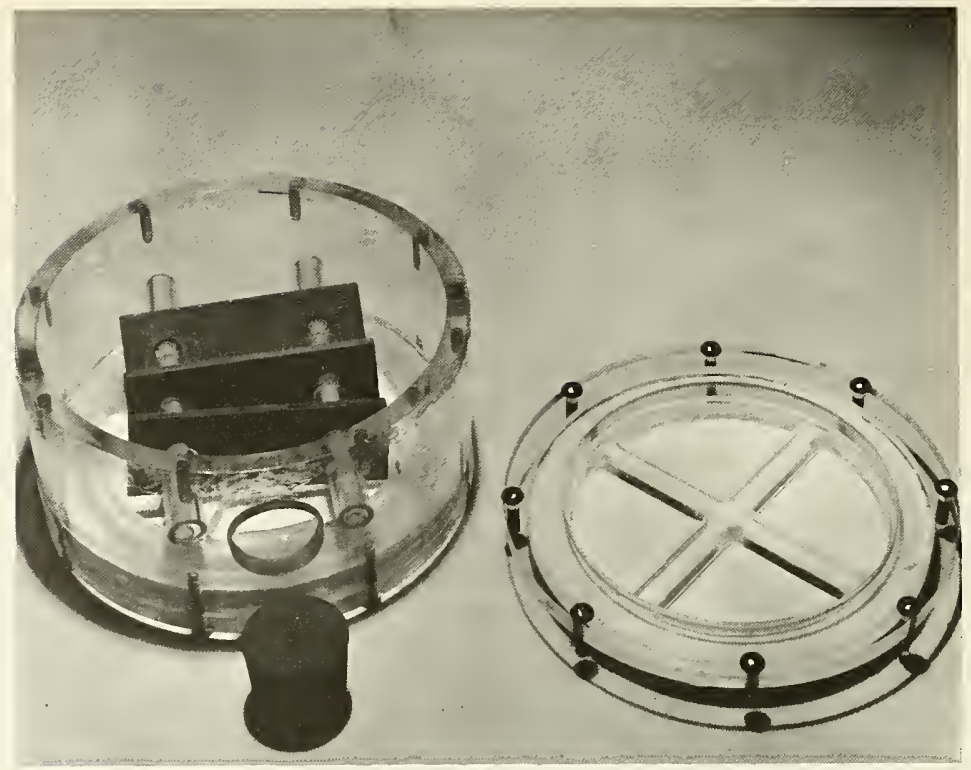

Figure 1. Cylindrical test chamber with assembled control panels inside. The end plate with membrane filter is shown at right.

$\mathrm{pH}$ of seawater samples inside and outside the test chamber were found to be identical. The test specimens which were placed inside these test chambers were intended to serve as control panels. ${ }^{*}$

2. Covered with a 210-mesh nylon screen cloth. Nylon screen cloth was placed between two plastic end plates that were cemented together along the edges, and these end pieces were sealed with silicone adhesive and attached to the cylinder with machine screws. Only microorganisms and larval forms of marine organisms can pass through the nylon screen cloths. The flow of seawater (currents) through the screen is very slight.

3. Uncovered. The plastic end plates without any coverings were placed over the ends of the test cylinder primarily to retain test specimens inside. The test panels would be subjected to fairly strong currents flowing through the uncovered ends and to attachment by various marine organisms.

\footnotetext{
* These specimens became contaminated with bacteria, as is discussed later in this report.
} 
The above plastic cylinders with test specimens were attached to cylindrical stainless steel brackets, which were secured to a 10-foot-long aluminum corrosion rack and exposed in the sea (Figure 2).

\section{Design of Plastic Specimen-Exposure Strips}

For total marine exposure (not in test chambers), some test panels were also secured to a $1 / 8 \times 2 \times 12$-inch plastic strip with nylon nuts and bolts. The plastic strips were cut from phenolic laminated plastic sheet. A small plastic washer was placed between the test panel and the plastic strip to expose as much metal surface area as possible to the seawater environment. The phenolic strips with test panels, together with test cylinders were then secured to a 10-foot-long aluminum corrosion rack for exposure in the sea (Figure 2). These panels are designated exposed panels.

The length of submergence, the number of test panels placed inside each test chamber and on plastic strips, and other information are presented in Table 1.

\section{Sterilization of Test Chambers}

The plastic test chambers covered with membrane filters and the rubber stoppers were sterilized by submerging them in a $0.25 \%$ chlorine solution (sodium hypochlorite) for 20 minutes. The germicidal effects of this chlorine concentration in distilled water was tested by inoculating the solution with various species of marine bacteria and conducting a standard laboratory bacteriological test on the inoculated water samples. It was found that the $0.25 \%$ chlorine concentration destroyed all the bacteria present in the water within 5 minutes.

\section{Shallow-Water Exposure Site}

Test specimens were submerged in the sea off the end of 400-foot-long Point Mugu Pier, which is located at the head of the Mugu Canyon facing the open ocean (Figure 3). The water depth is about 20 to 25 feet during high tide at this location. It was believed this location would subject the test panels to strong tidal currents and to attachment by various fouling organisms normally found in this area. Rough seas are normally encountered during the winter months (December to March). 


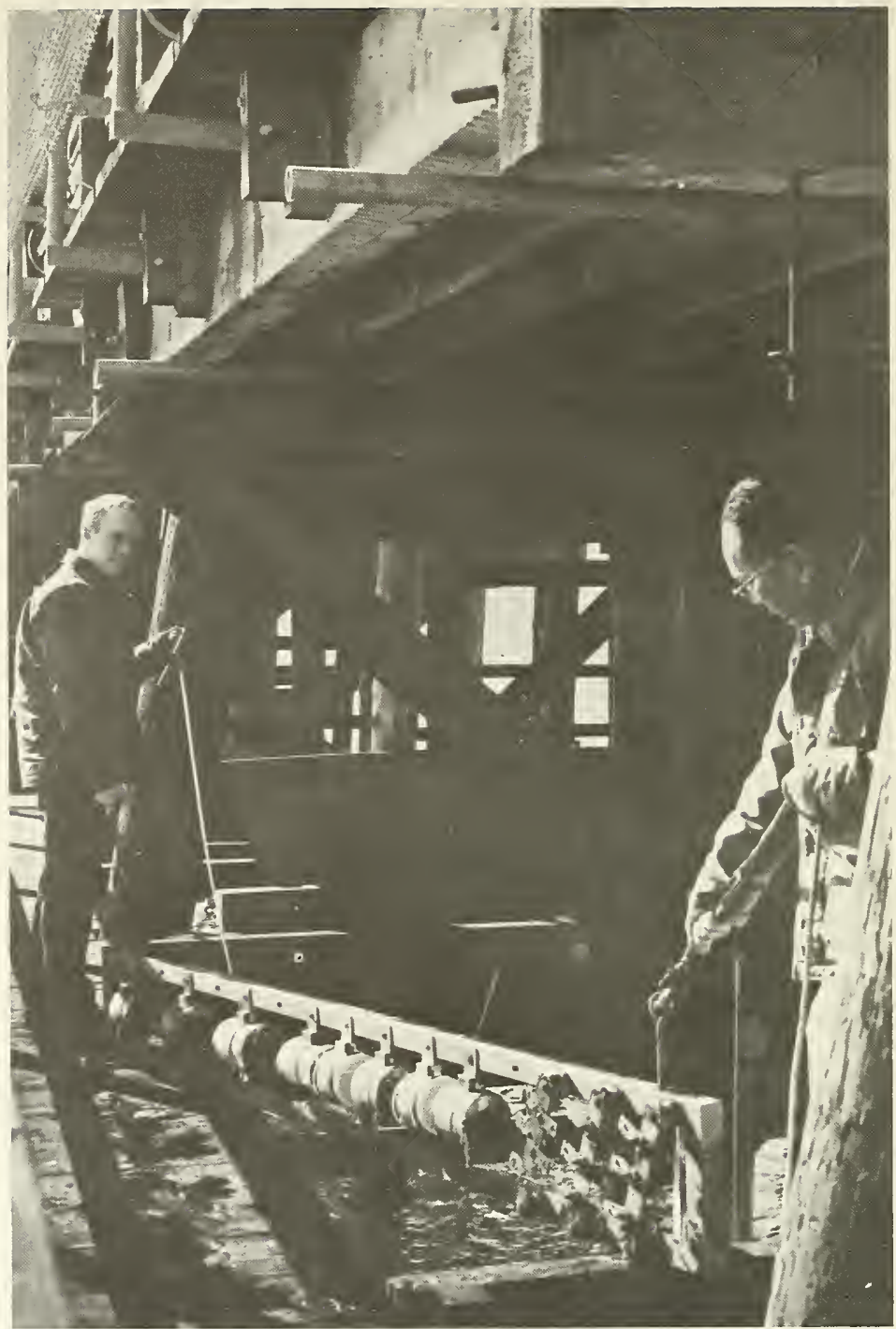

Figure 2. Cylindrical test chambers and plastic strips with test panels attached to a 10-foot-long corrosion rack for exposure in the sea. 


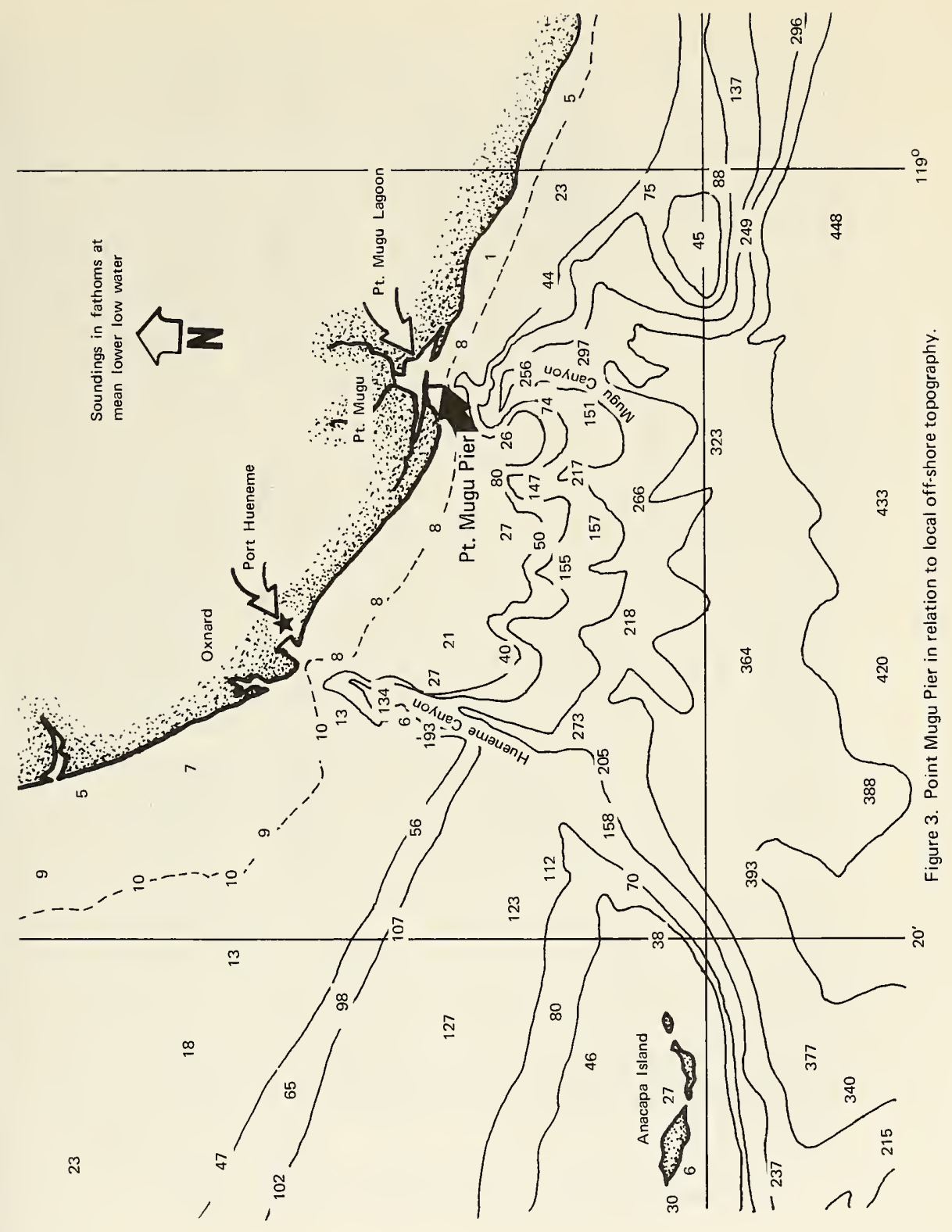




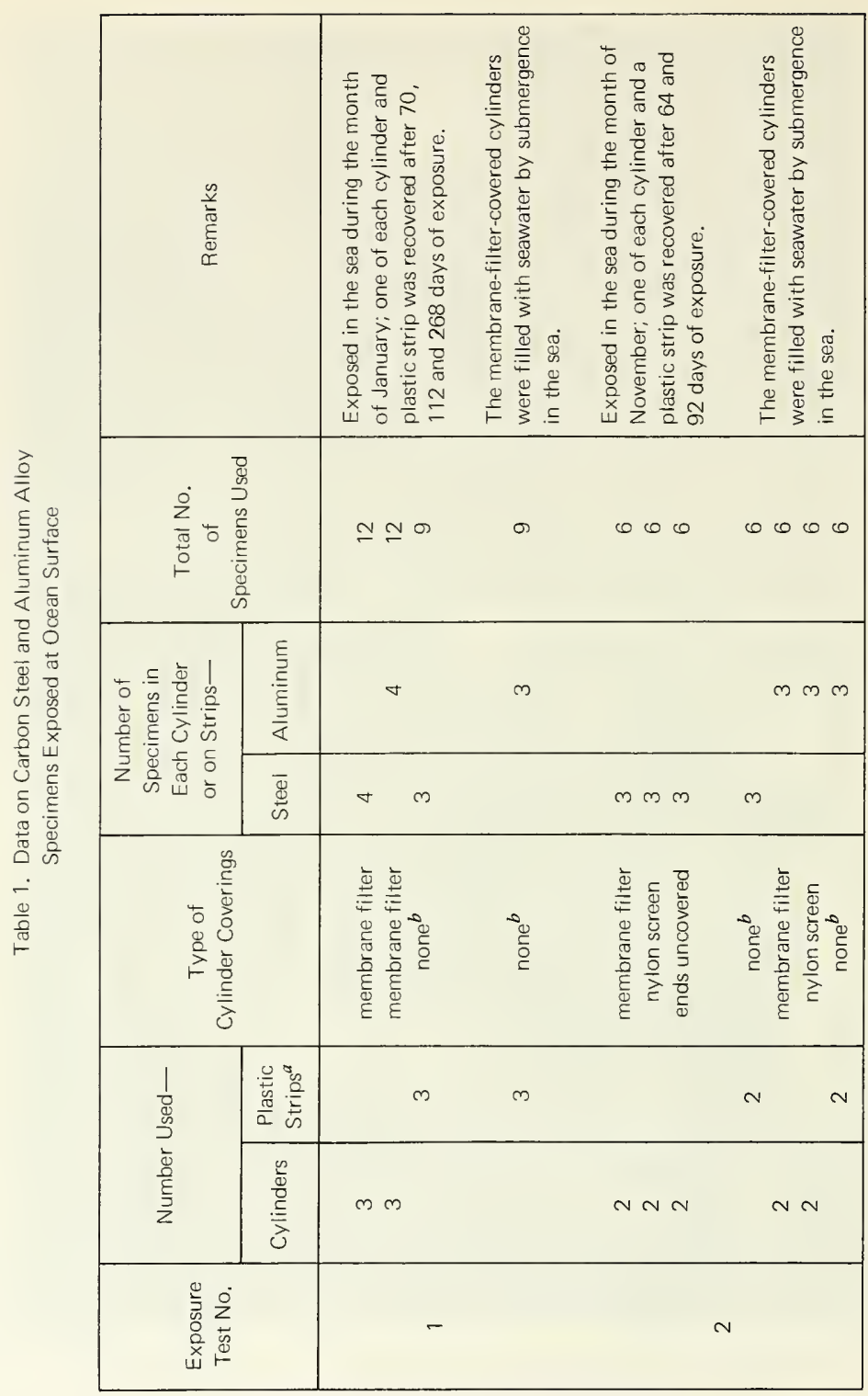




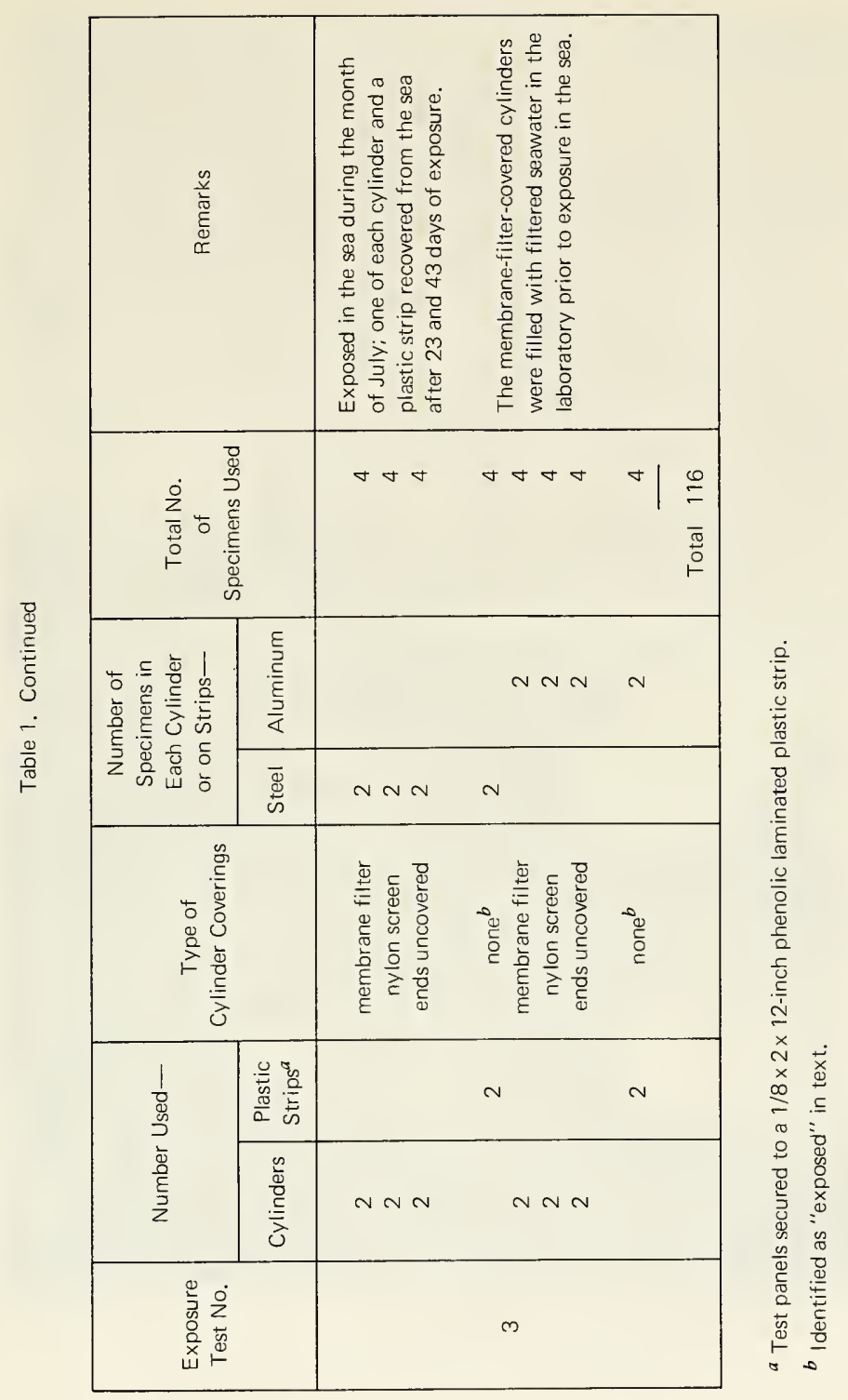




\section{Analysis of Seawater}

Chemical Tests. Seawater samples were collected at (1) 10 feet below the surface (at high tide) because the test specimens were submerged at this depth, and (2) from inside the recovered test chambers covered with membrane filters. The seawater samples were tested for dissolved oxygen concentration, $\mathrm{pH}$, salinity, temperature, and microorganisms. The seawater samples from inside the test chamber sealed with membrane filters were carefully collected using an automatic pipetting device (Figure 4). This device was used primarily because it collects seawater without exposing it to aeration during collecting operation. The dissolved oxygen values were determined by the Winkler Method and the salinity values were determined by means of an inductive salinometer using Copenhagen seawater as a standard. The $\mathrm{pH}$ was determined by using a Beckman Model $\mathrm{N}$ pH Meter.

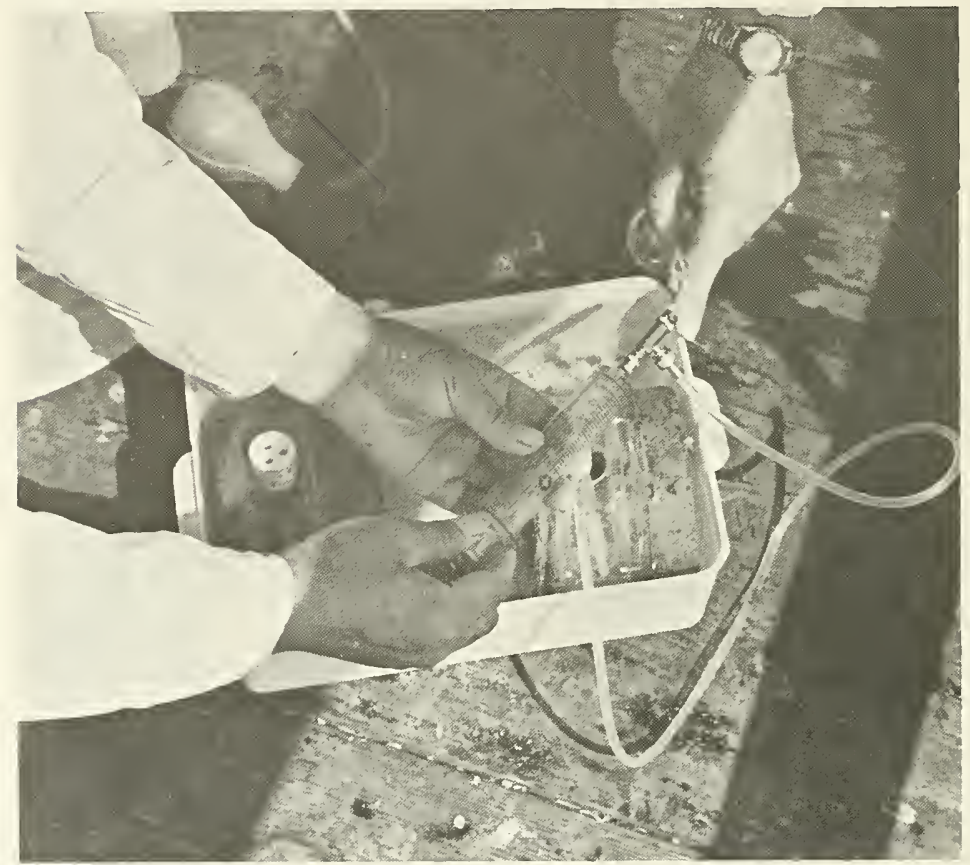

Figure 4. Automatic pipetting device used to collect undisturbed seawater samples for chemical analyses from inside a cylindrical test chamber. 


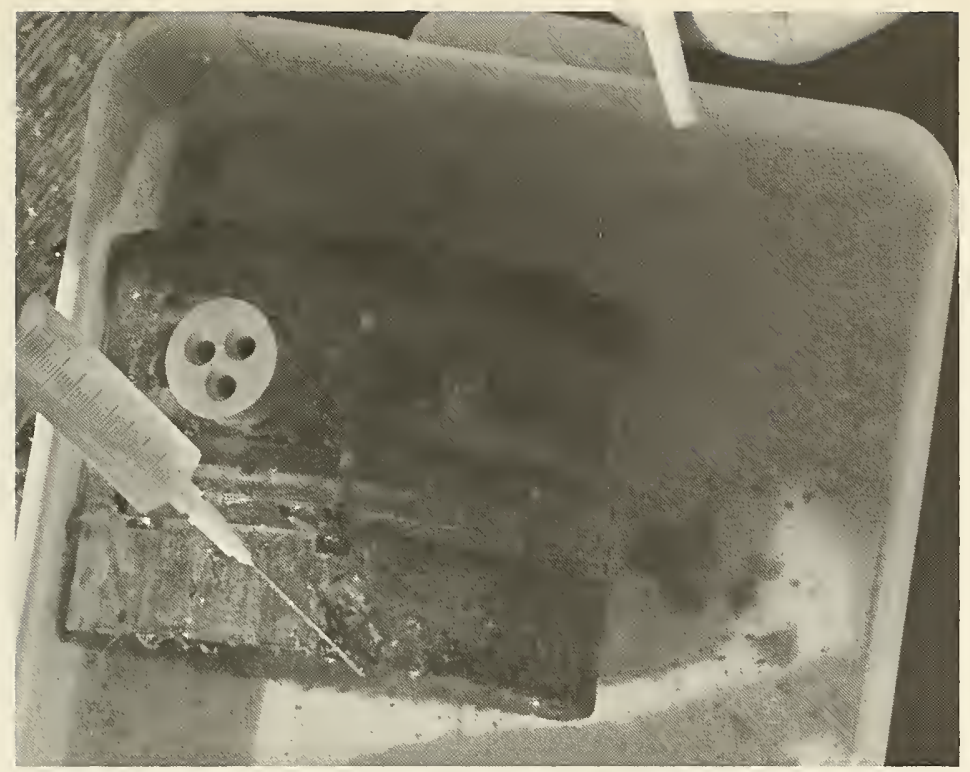

Figure 5. Sterile syringe is used to collect seawater sample through countersunk hole in rubber stopper for bacteriological analysis.

Bacteriological Tests. The seawater samples from inside the recovered test chambers covered with membrane filters were obtained aseptically by inserting the needle of a sterile hypodermic syringe through a countersunk hole in the rubber stopper, the exposed part of which was cleaned, washed, and sterilized with ethyl alcohol (Figure 5). A sterilized ZoBell bacteriological water sampler was used to collect seawater samples from 10 feet below the surface (at high tide) off the end of Point Mugu Pier for bacteriological analyses.

In the laboratory, the collected water samples were filtered through a 0.45-micron membrane filter. Upon completion of the filtration, the filters were placed on the surface of a nutrient agar medium to culture the viable microorganisms caught on their surfaces. The nutrient medium was developed by Morita and ZoBell for growing marine bacteria. ${ }^{12}$ After several days of incubation, the small bacterial colonies growing on the surface of the filter papers were examined and counted under a stereoscopic microscope. 


\section{Evaluation of Test Specimens}

After the test specimens were recovered from the sea, they were examined visually for gross corrosion damage and fouling attachment. The corrosion products and the attached fouling organisms were then removed from the test specimens as described under "Preparation of Test Specimens." The panels were processed twice through the chemical cleaning procedure and the final weight change determined and recorded. The weight loss due to chemical cleaning on control panels was also determined and taken into account during final evaluation of marine corrosion. The weight losses due to corrosion are expressed in milligrams lost per square decimeter of exposed surface per day (mdd). This unit was converted to indicate depth of penetration as mils per year (mpy).

\section{RESULTS AND DISCUSSION}

\section{Shallow-Water Tests}

Exposure Test No. 1 (70, 112, and 268 Days). The carbon steel and aluminum alloy test panels were exposed in the sea beginning in the month of January in two ways as follows: (1) placed inside cylindrical test chambers sealed.with membrane filters (control panels), and (2) placed on phenolic plastic strips (exposed panels).

When the panels were recovered after 70 days in the sea, the exposed steel and aluminum alloy panels were covered primarily with a light growth of Ectocarpus (brown algae), hydroids, and corrosion products (Figure 6). The control panels were free of any marine growth. However, the surfaces of these control steel panels were covered uniformly with a fine, powder-like red rust (Figure 7). A small amount of white corrosion products had formed over the edges and ends of control aluminum alloy panels; however, the surfaces were relatively free of such corrosion products (Figure 8). The condition of the exposed and control panels after undergoing chemical cleaning is shown in Figures 9 through 13. The surfaces of exposed steel panels were irregular (rough), while the surfaces of the control panels were relatively smooth. The exposed aluminum alloy panels had numerous shallow and deep pits over their surfaces. Severe corrosion had also occurred along the edges and ends of these panels. On the other hand, the control aluminum alloy panels were free of surface corrosion or pittings, but minute corrosion did occur along the edges and ends of these panels. 


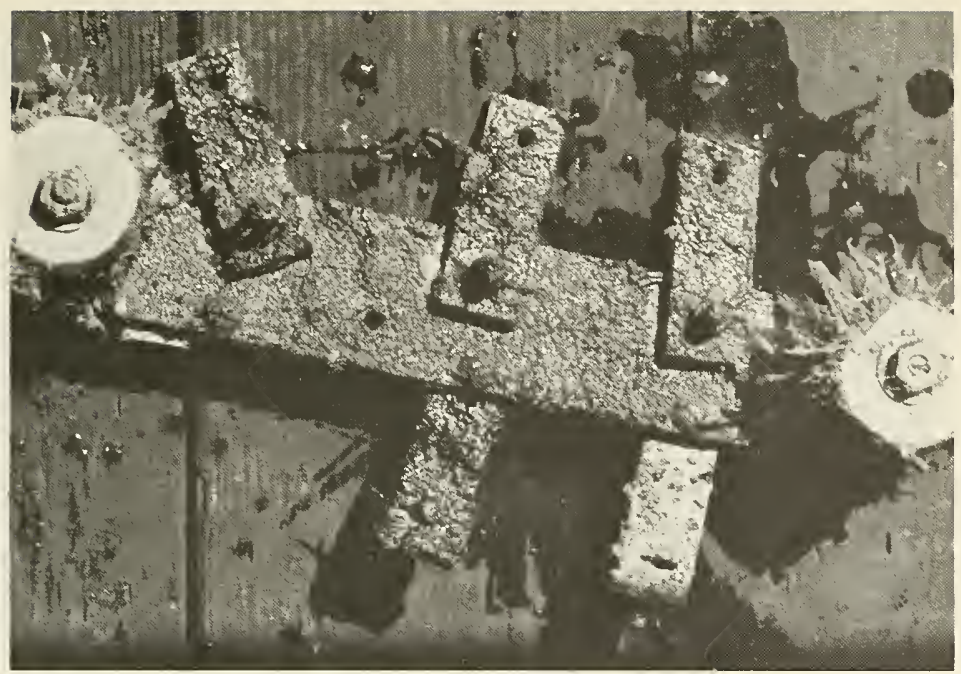

Figure 6. Exposed test specimens on a plastic strip covered with marine growth and corrosion products (70 days). Top—steel; bottom-aluminum alloy.

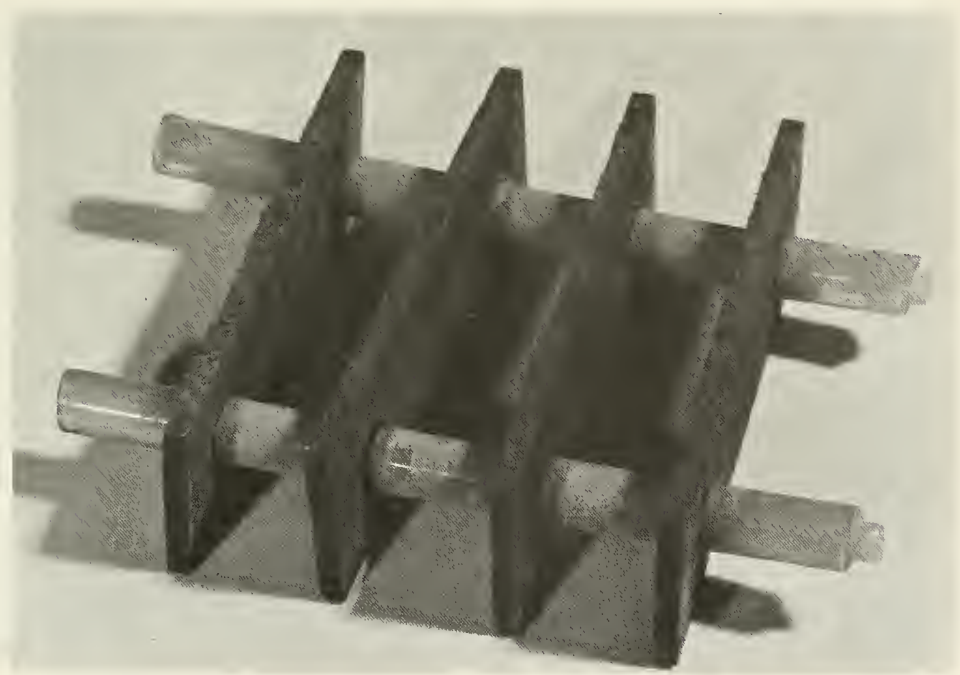

Figure 7. Steel control panels removed from test chamber are covered with powderlike red dust particles (70 days). 


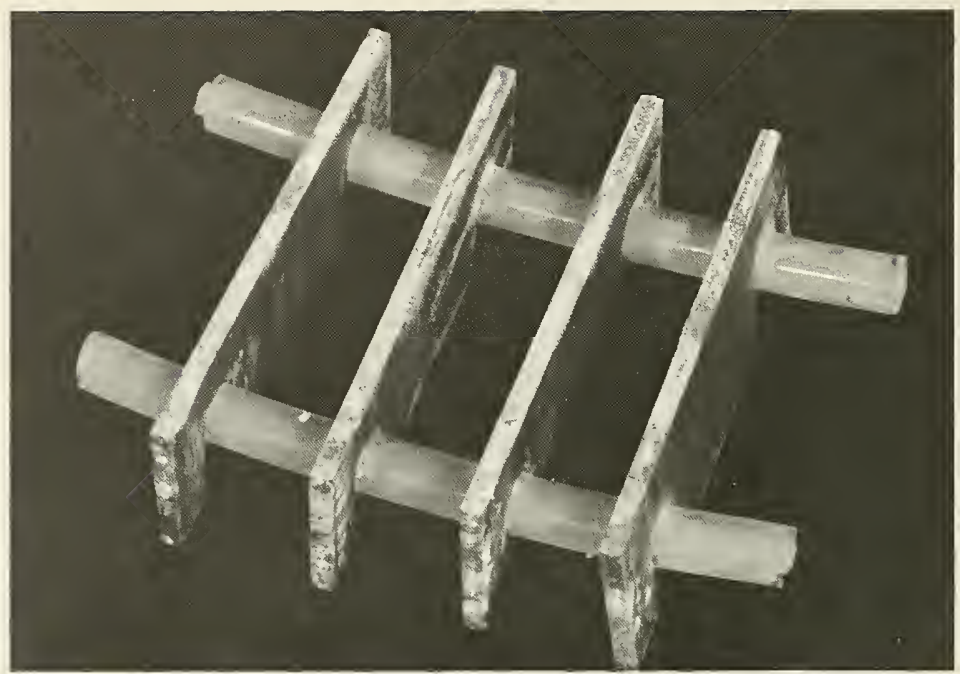

Figure 8. White corrosion products are present on the edges and ends of control aluminum alloy panels exposed inside a test chamber ( 70 days).

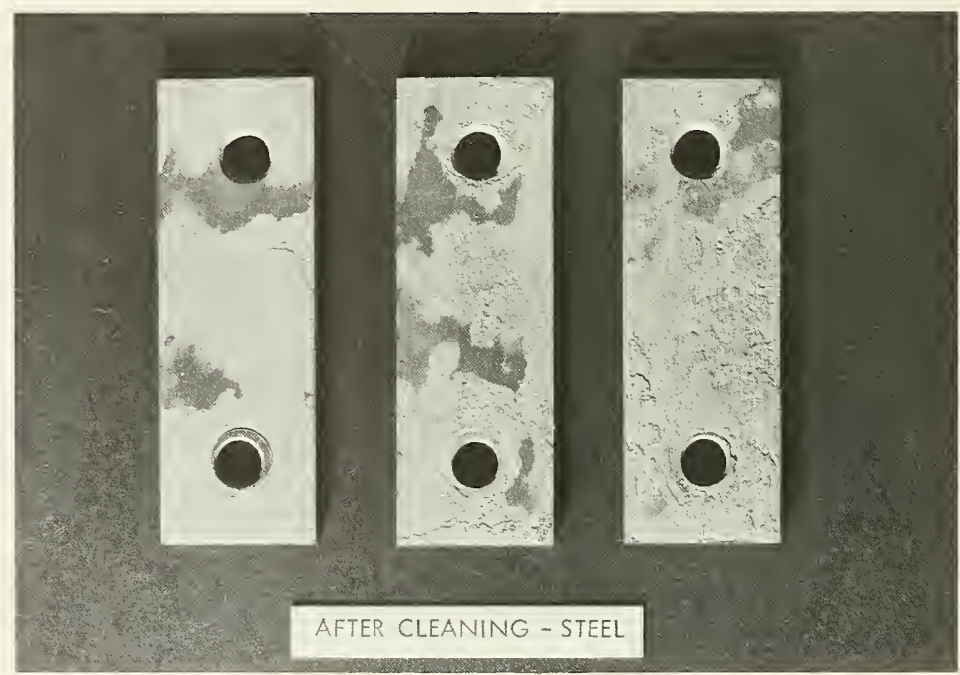

Figure 9. Chemically cleaned steel exposed panels showing irregular surface corrosion (70 days). 


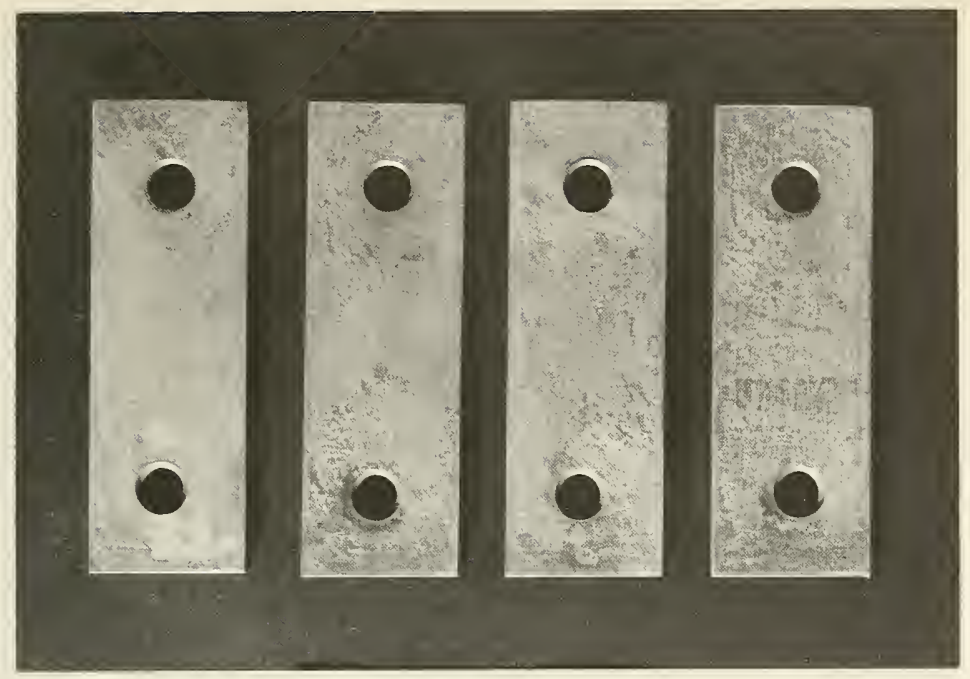

Figure 10. Chemically cleaned steel control panels showing uniform surface corrosion (70 days). (Same panels shown in Figure 7.)

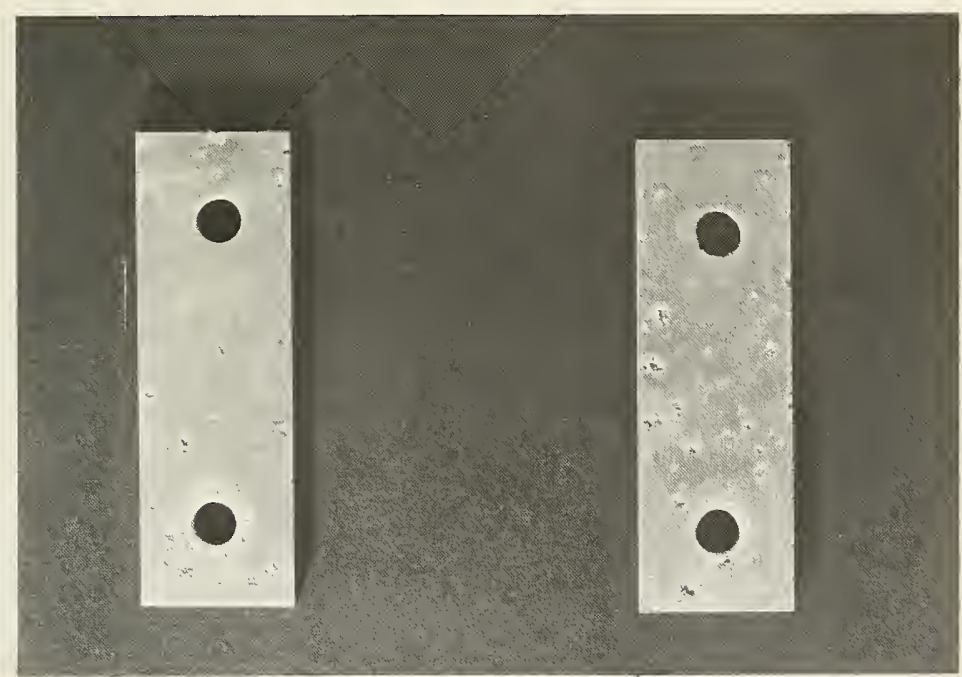

Figure 11. Chemically cleaned aluminum alloy exposed panels showing pitting corrosion over surfaces (70 days). (Same panels shown in Figure 6.) 


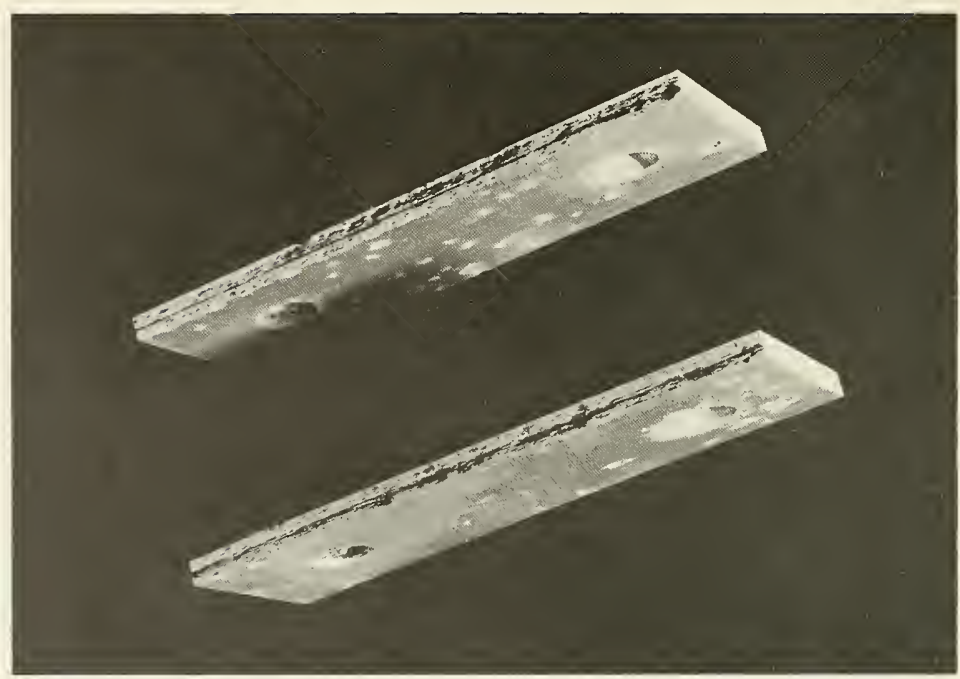

Figure 12. Severe corrosion found along edges of aluminum alloy exposed panels (70 days). (Same panels shown in Figures 6 and 11.)

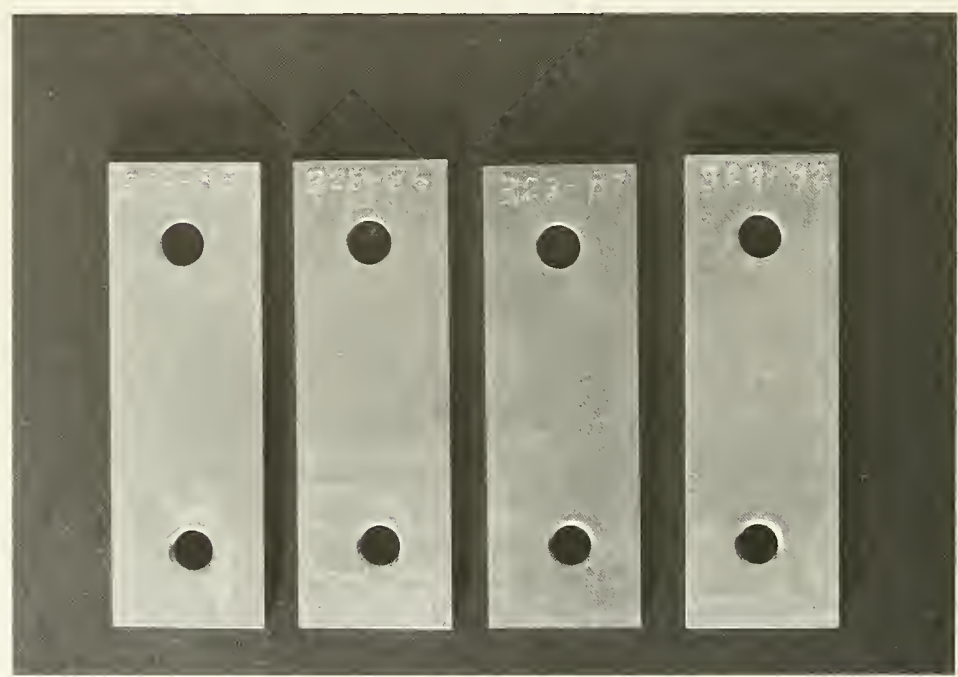

Figure 13. Aluminum alloy control panels were free of pitting corrosion on surfaces (70 days). (Same panels shown in Figure 8.) 
The corrosion rates of test panels exposed for 70 days in the sea are presented in Table 2. The corrosion rates of steel control panels were $1.12 \mathrm{mpy}$ as compared to $13.80 \mathrm{mpy}$ for exposed panels. The corrosion rates of aluminum alloy control panels were $0.42 \mathrm{mpy}$ as compared to $8.19 \mathrm{mpy}$ for exposed panels (Table 2).

When bacteriological tests were conducted on seawater samples collected from inside the initially sterile cylindrical test chambers, approximately 1,000 bacteria (single species) per $\mathrm{ml}$ of seawater were isolated. It is not known what effect these bacteria had on the corrosion rates of control test panels, nor is it known how or when the seawater became contaminated with these microorganisms.

Further bacteriological tests conducted on the bacteria collected from the water samples showed that these were small gram-negative, spore-forming, rod-shaped bacteria. These bacteria grew exceptionally well and rapidly in a test tube containing nutrient broth made with seawater, but grew very slowly and very poorly in a nutrient broth made with distilled water. Identical bacteria were isolated from inside sterile test chambers used in Exposure Tests nos. 2 and 3.

Dissolved oxygen concentration was not determined from these water samples because large amounts of air were introduced into the samples during collecting operation. The automatic pipetting device was not available for use at this time.

The exposed steel and aluminum alloy specimens submerged in the sea for 112 days were covered with a denser marine growth than the 70-day panels. Fouling on the panels included barnacles, calcareous tubeworms, branching and encrusting bryozoans, some algae, kelp, and corrosion products (Figure 14). After the corrosion products and marine growth were removed from these panels by washing, scrubbing, and cleaning in a chemical solution, the steel showed some corrosion on the surface (irregular surface) as shown in Figure 15. The aluminum alloy showed pitting on the surface (Figure 16) and also severe corrosion along the edges of the panels (Figure 17). The steel and aluminum alloy control panels were relatively free of corrosion and pitting (Figure 18), but there was some corrosion along the edges of aluminum alloy panels (Figure 19). The average corrosion rates for the 112 days of exposure are presented in Table 2. Bacteria were again found in seawater samples in which control panels were exposed.

After 268 days in the sea, the exposed steel and aluminum alloy panels were completely covered with a very dense growth of branching bryozoans (Figure 20). Underneath this growth, other sessile organisms such as tubeworms, barnacles, and encrusting bryozoans were found attached to the surfaces of the test panels (Figures 21 and 22). The surfaces of the carbon 
steel specimens were covered with a thick red rust on which were fouling organisms. Since the surfaces of the aluminum alloy panels were not covered with a layer of corrosion products, large numbers of marine organisms were attached directly onto the surface and were very difficult to remove. The 3/4-inch-diameter baseplate of a barnacle was securely attached to the surface of an aluminum panel, and it was especially difficult to remove (Figure 22).
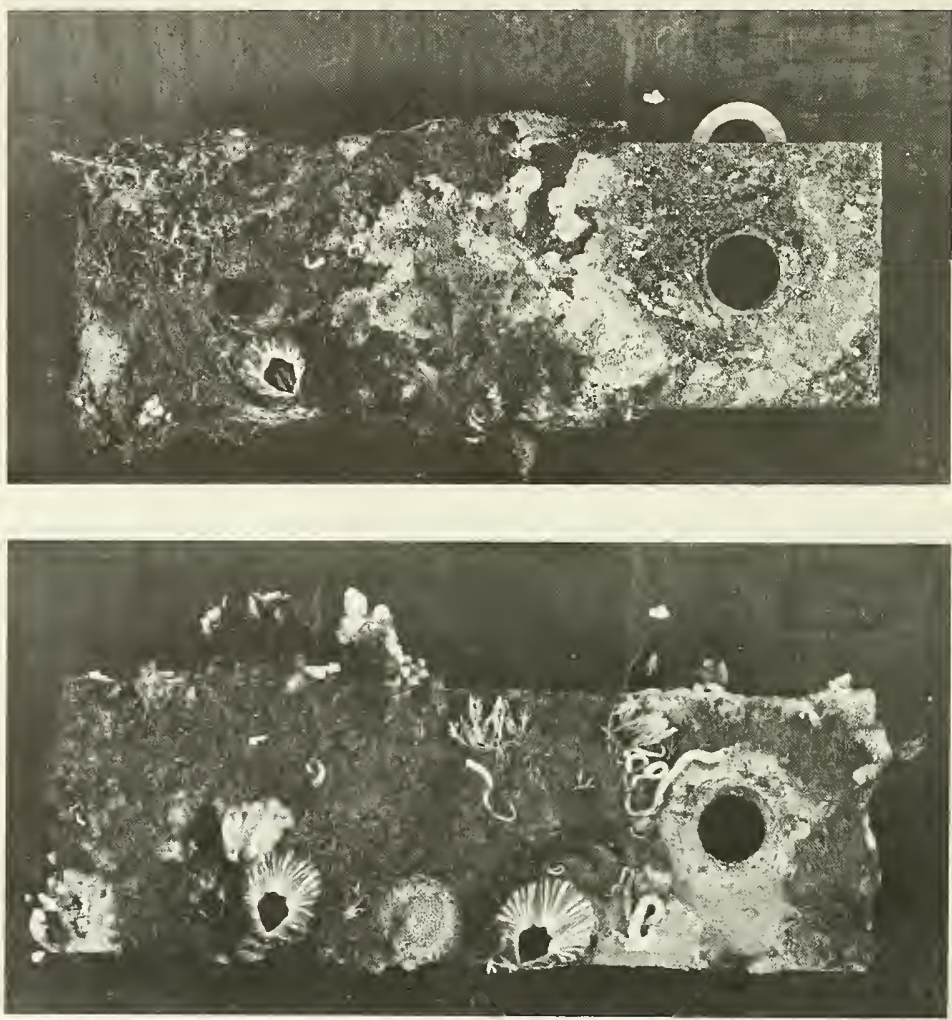

Figure 14. Exposed carbon steel (top) and aluminum alloy (bottom) panels covered with marine growth and corrosion products ( 112 days). 


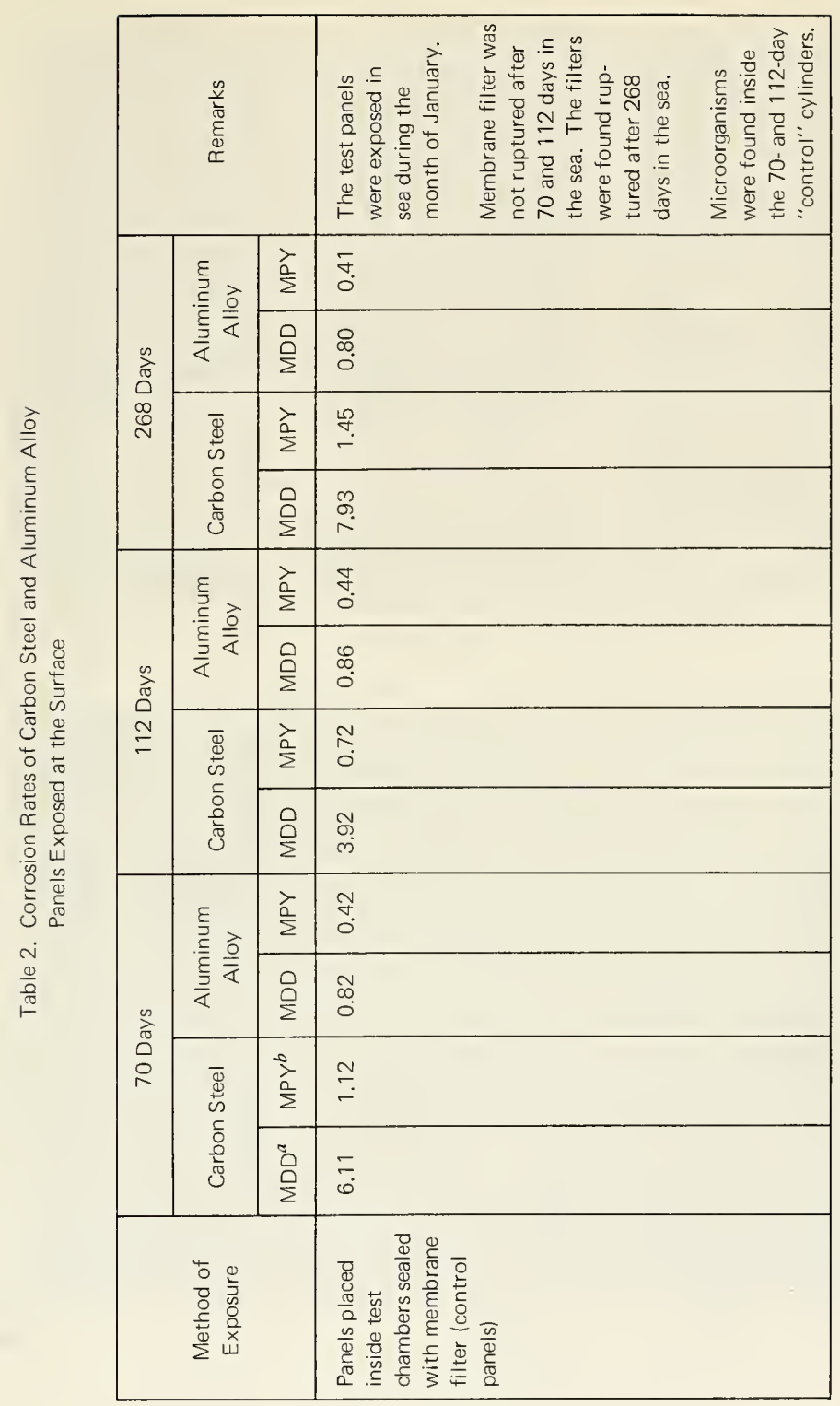




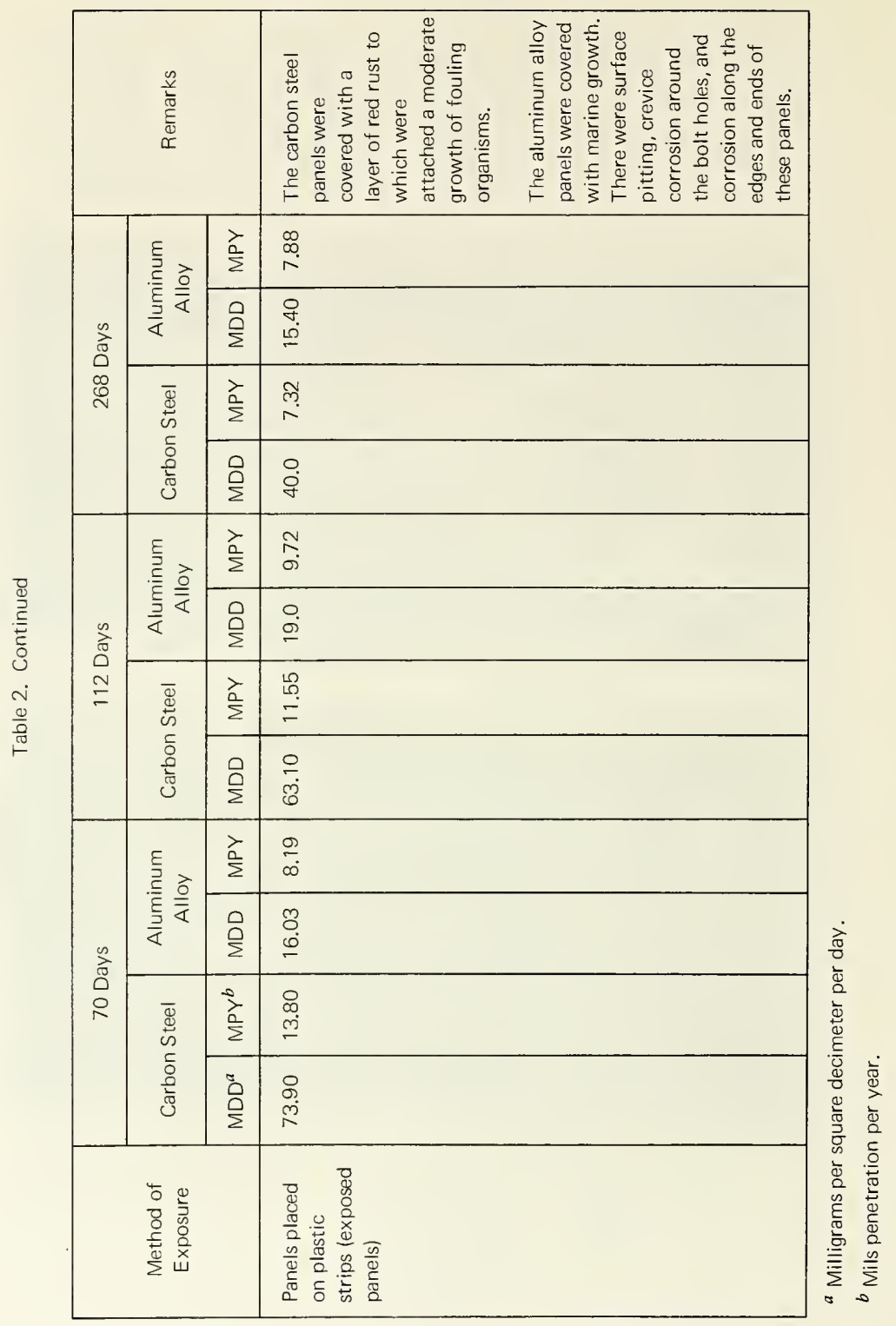




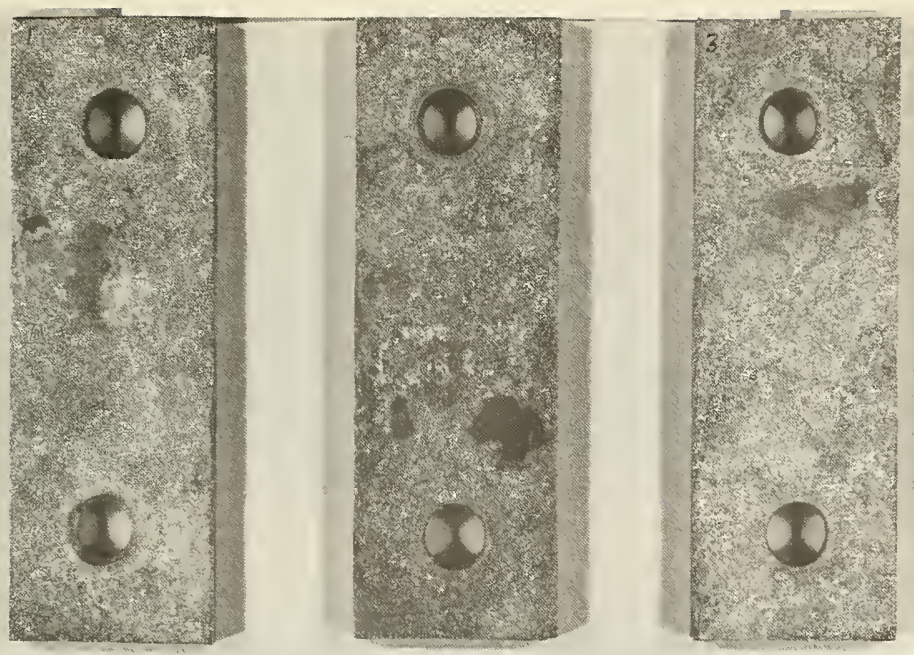

Figure 15. Exposed steel panels after cleaning with chemical solution (112 days).

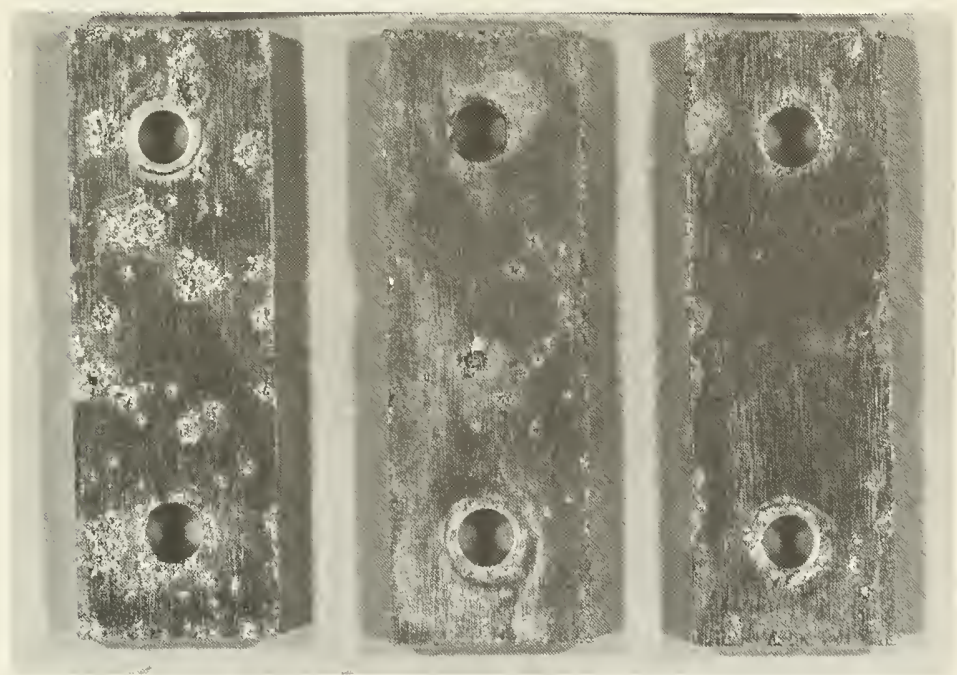

Figure 16. Exposed aluminum alloy panels after chemical cleaning showing pitting corrosion over surfaces and crevice corrosion around edges of holes (112 days). 


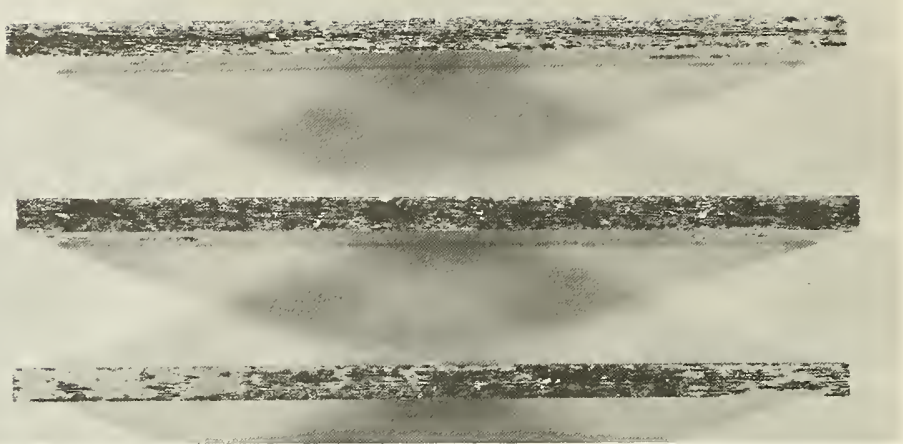

Figure 17. Severe corrosion is found along edges of exposed aluminum alloy panels (112 days).
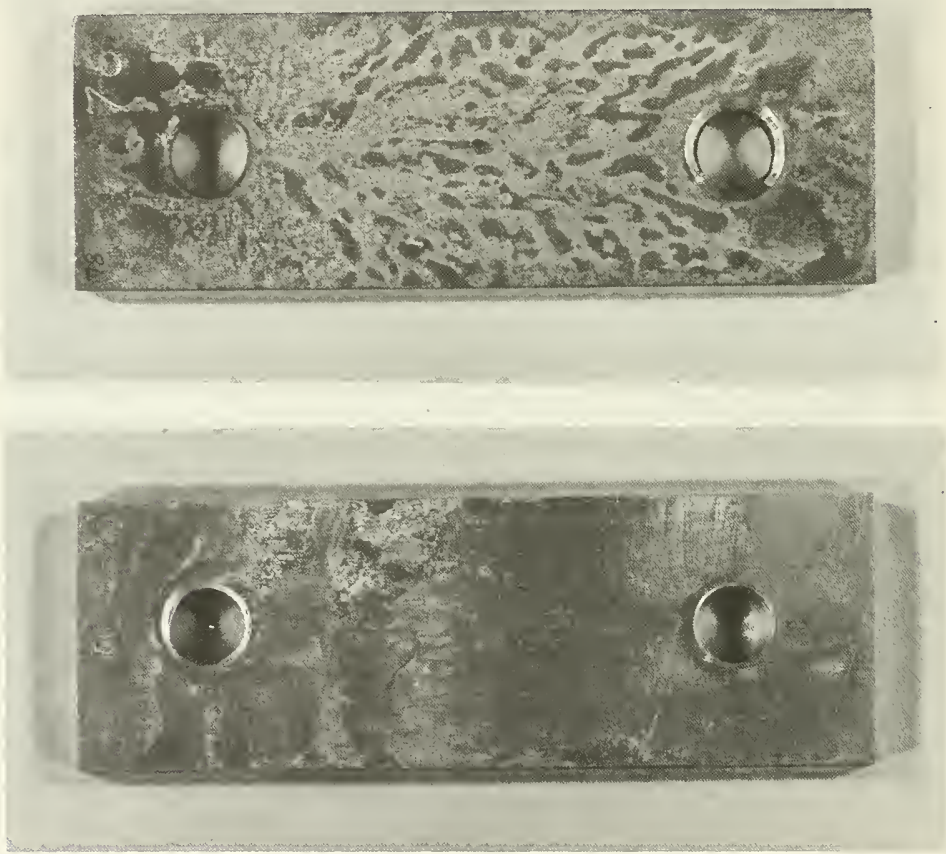

Figure 18. Chemically cleaned carbon steel (top) and aluminum alloy (bottom) control panels which were exposed inside test chambers ( 112 days). 


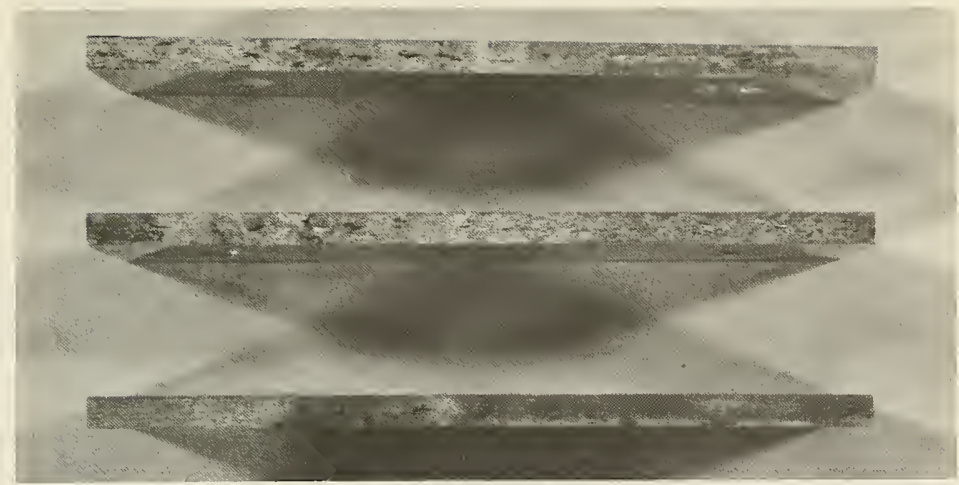

Figure 19. Slight corrosion is found along edges of aluminum alloy control panels exposed inside test chamber (112 days).

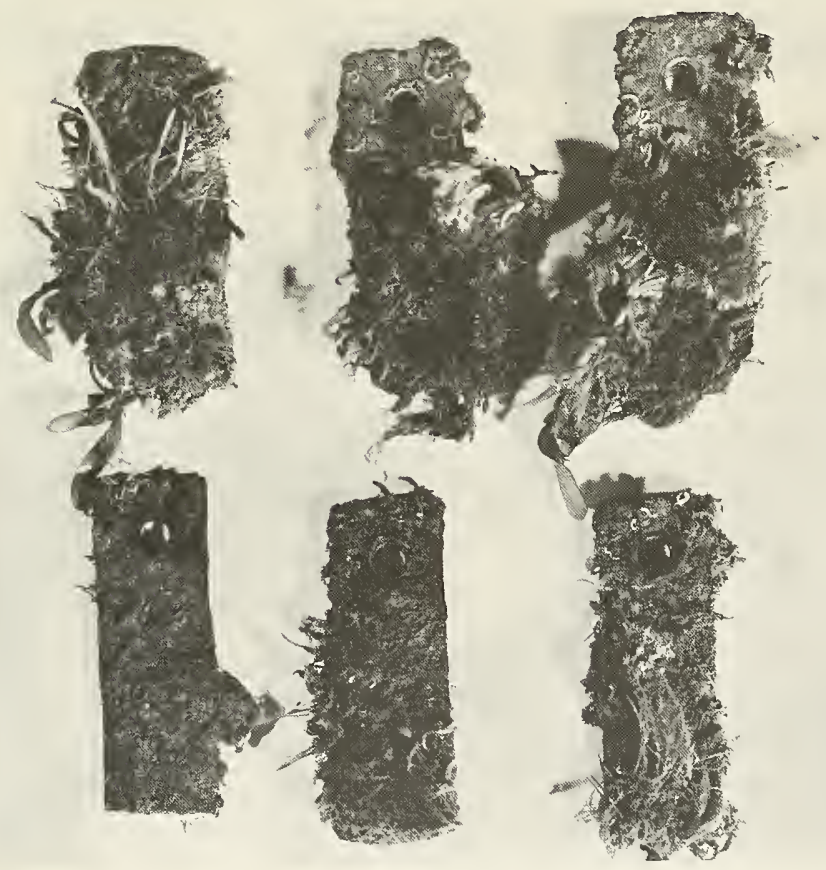

Figure 20. Dense marine growth and heavy corrosion products formed over exposed steel and aluminum alloy test specimens (268 days). 

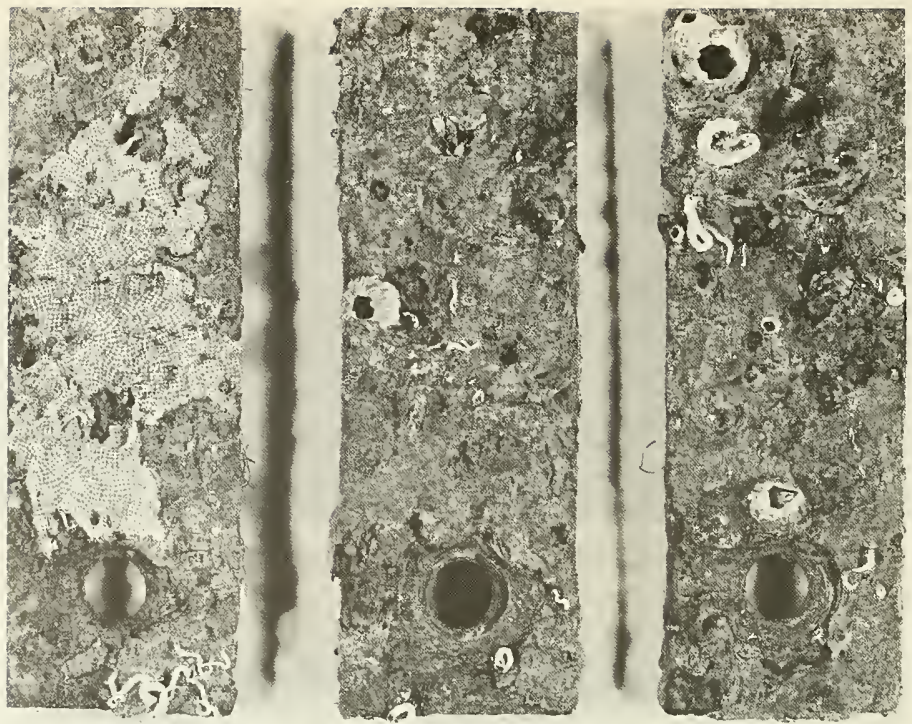

Figure 21. Encrusting bryozoan (left panel), tubeworms, barnacles, and coating of rust found over exposed steel panels. (Same panels shown in Figure 20.)

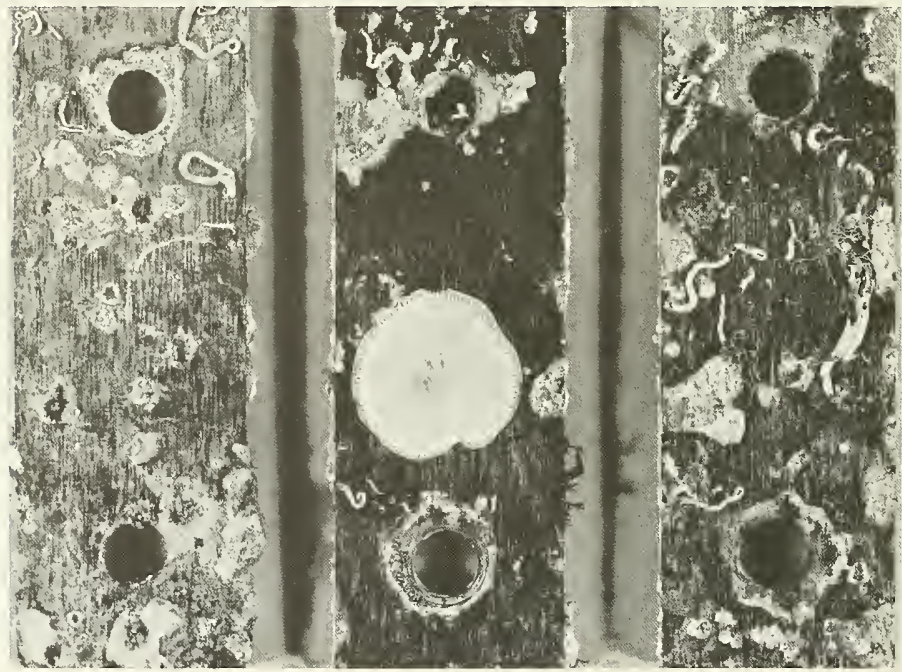

Figure 22. Tubeworms, large baseplate of barnacle (center panels), and pitting corrosion found over aluminum alloy exposed panels. (Same panels shown in Figure 20.) 
The membrane filter coverings over cylindrical test chambers in which the control panels were placed were found to be ruptured when the test chambers were recovered after 268 days in the sea. The acrylic plastic cylinders were covered primarily with branching and encrusting bryozoans and hydroids (Figure 23). The steel panels which had been placed inside one of these cylinders were covered uniformly with a paperlike thin film of red rust instead of the powderlike flaky red rust found on control panels exposed 70 and 112 days (Figure 24). The aluminum alloy panels were relatively free of corrosion products. However, there were a few calcareous tubeworms growing on the panels (Figure 24). The chemically cleaned exposed and control panels are shown in Figures 25 through 27. The corrosion rates of the panels exposed for 70,112 , and 268 days in the sea are presented in Table 2 and shown graphically in Figure 28.

Exposure Test No. 2 (64 and 92 Days). The test panels were exposed in the sea beginning in the month of November. The corrosion rates were obtained by exposing the test panels in four different ways as follows:

1. Placed inside initially sterile cylindrical test chambers sealed with membrane filters (control panels). The sealed chambers with test specimens were filled with seawater by carefully submerging them in the sea at the exposure test site.

2. Placed inside cylindrical chambers with both ends covered with a nylon screen (Figure 29).

3. Placed inside cylindrical chambers with ends left open (Figure 30).

4. Placed on 2-inch-wide phenolic plastic strips (exposed panels).

After 64 days the steel and aluminum alloy control panels were free of any fouling growth, however, these panels were exposed to microorganisms that invaded the initially sterile cylinders sealed with membrane filters. The bacteria were morphologically similar to those isolated in Exposure Test No. 1. The exposed aluminum alloy panels (Figure 31 ) were covered with branching bryozoans and numerous small mussels (1/16-inch). The steel panels were covered with layers of loose corrosion products on which there were a few small mussels. Other marine organisms may have been washed off together with the loose corrosion products by currents. The panels placed inside cylinders with ends open were similarly affected. 


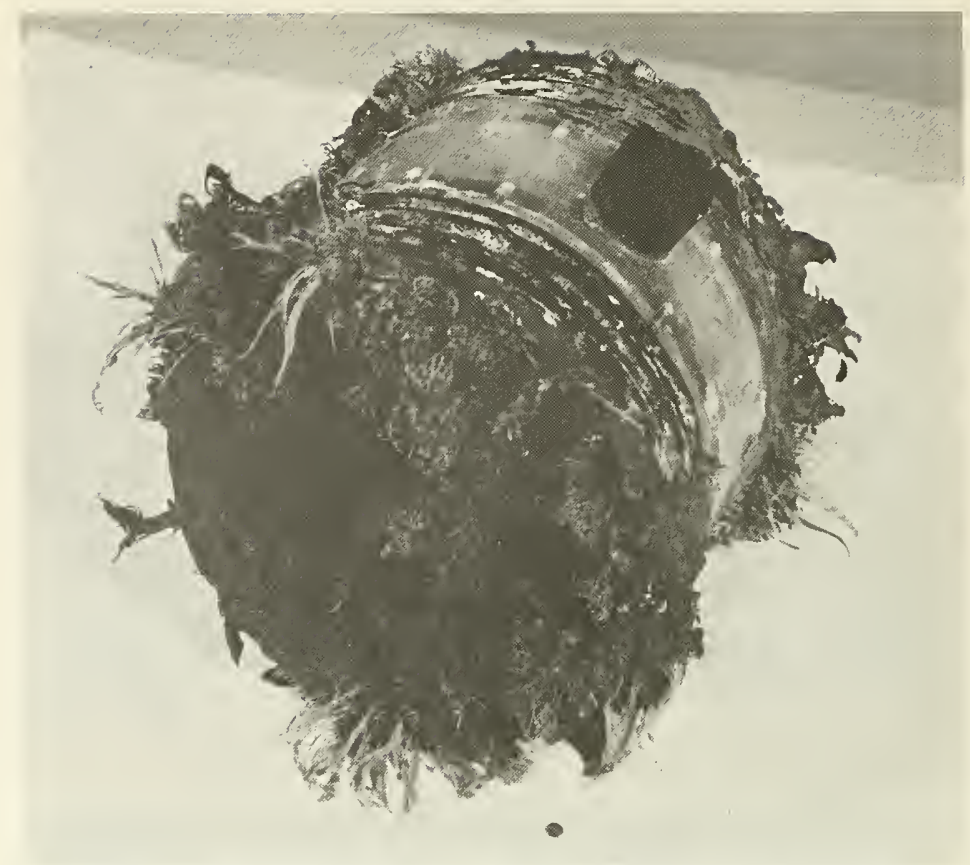

Figure 23. Dense marine growth (bryozoans) on cylindrical test chambers after 268 days in the sea.
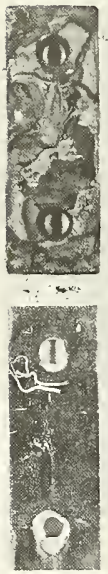
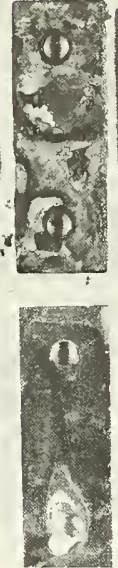
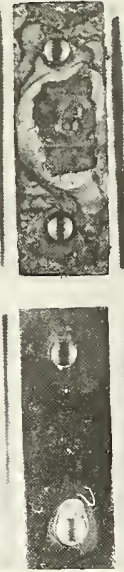

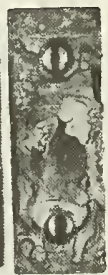

Figure 24. Carbon steel (top) and aluminum alloy (bottom) control panels. Surfaces of steel panels covered with uniform coating of paperthin corrosion products. Several tubeworms are present on the surfaces of aluminum alloy panels (268 days). The test panels were in cylindrical test chambers with ruptured membrane filter seal. 


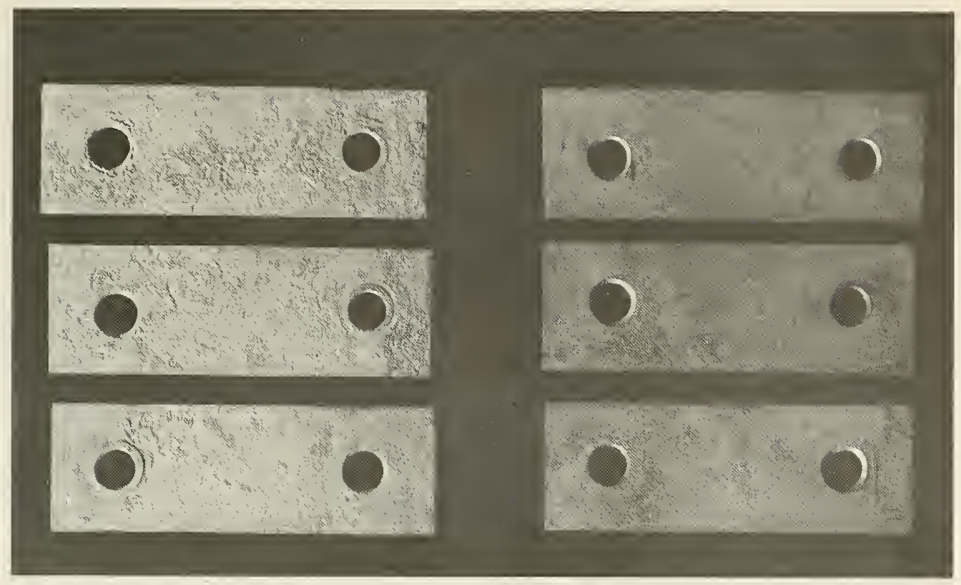

Figure 25. Chemically cleaned exposed (left) and control (right) steel panels. Surface corrosion is more irregular over exposed panels than over control panels (268 days). (Same panels shown in Figures 21 and 24.)

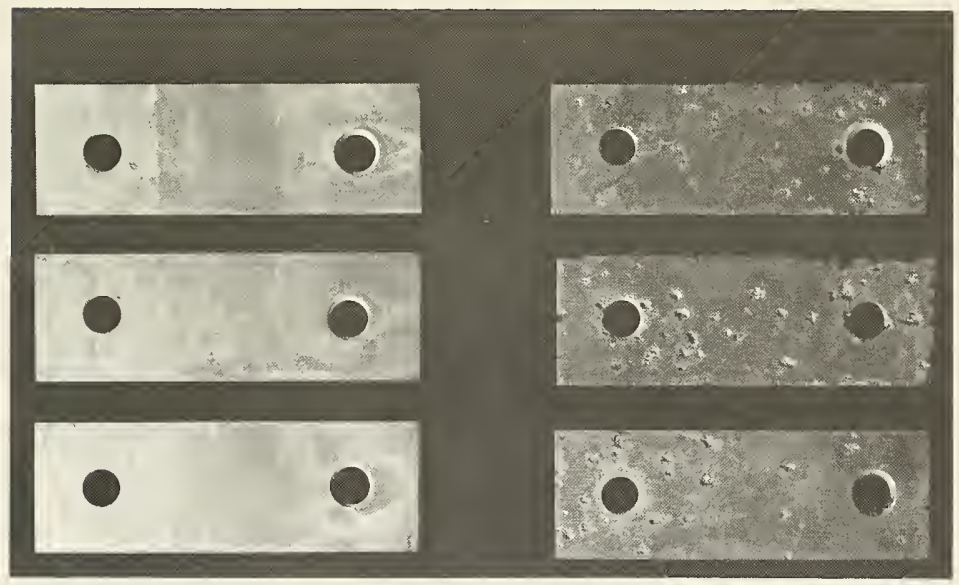

Figure 26. Chemically cleaned exposed (right) and control (left) aluminum alloy panels. Same panels shown in Figures 22 and 24. Severe pitting corrosion and also crevice corrosion are present over exposed (right) panels. Very light pitting and crevice corrosion were formed over control (left) panels (268 days). 


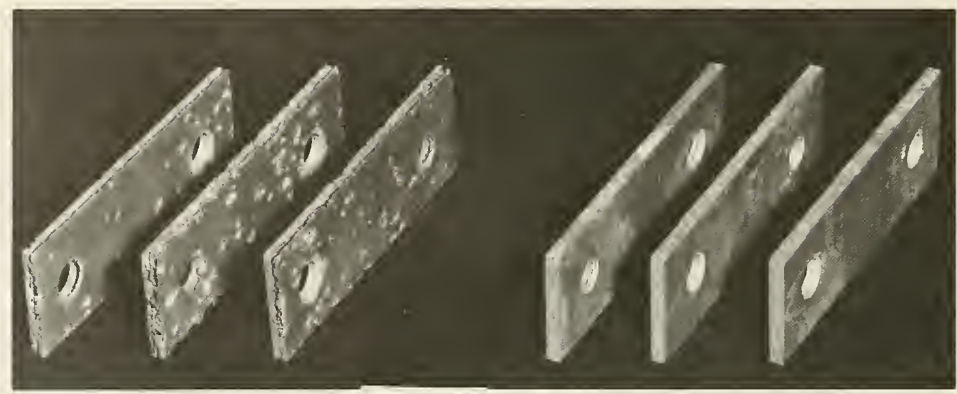

Figure 27. Corrosion along the edges and ends of exposed aluminum alloy panels is much more severe than over the edges and ends of control aluminum alloy panels (268 days).

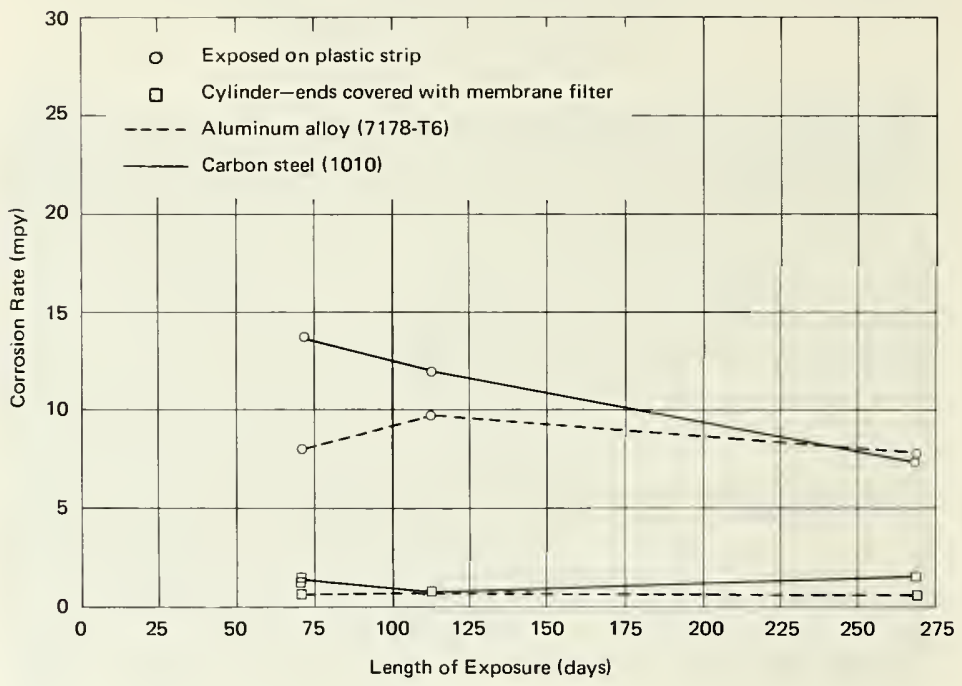

Figure 28. Corrosion rate of carbon steel and aluminum alloy exposed near ocean surface for 70,112 , and 268 days. 


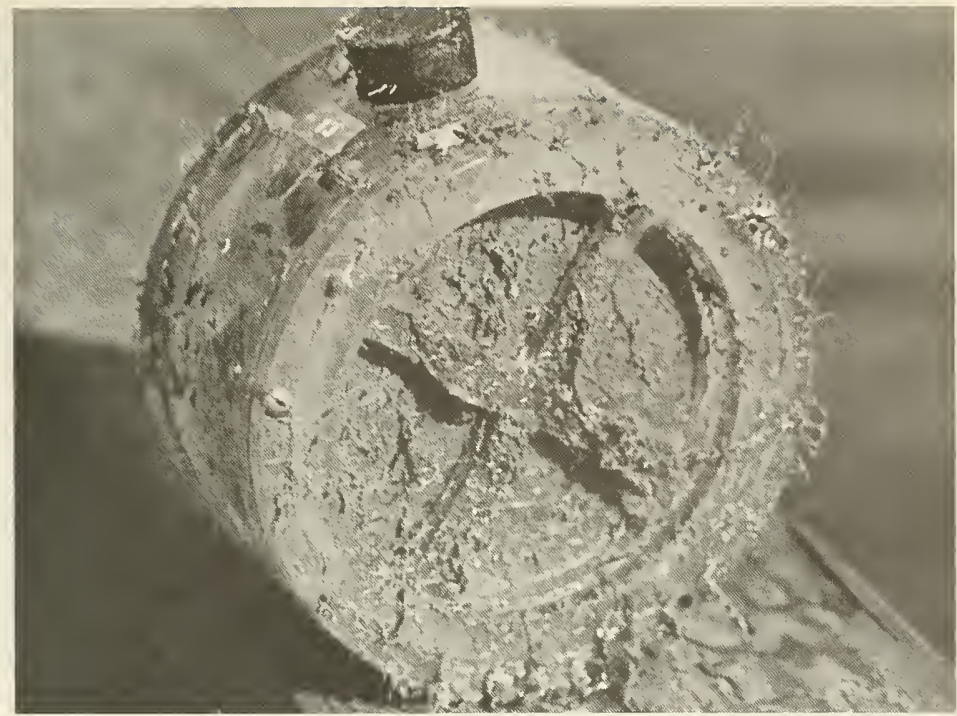

Figure 29. Plastic cylinder covered with nylon screen cloth (64 days).

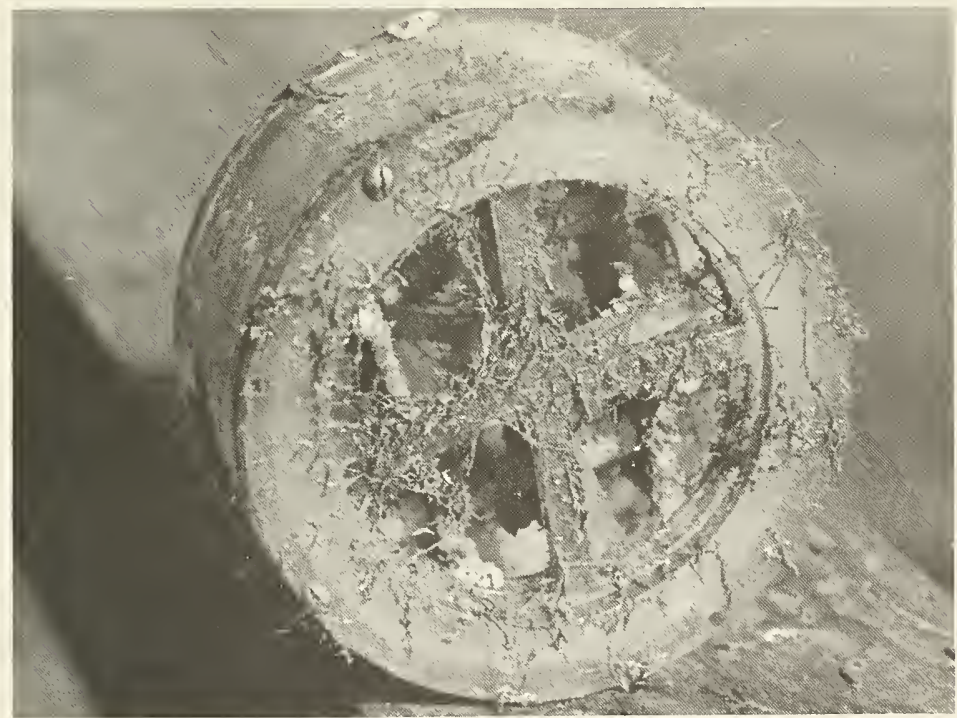

Figure 30. Plastic cylinder with its ends uncovered (64 days). 


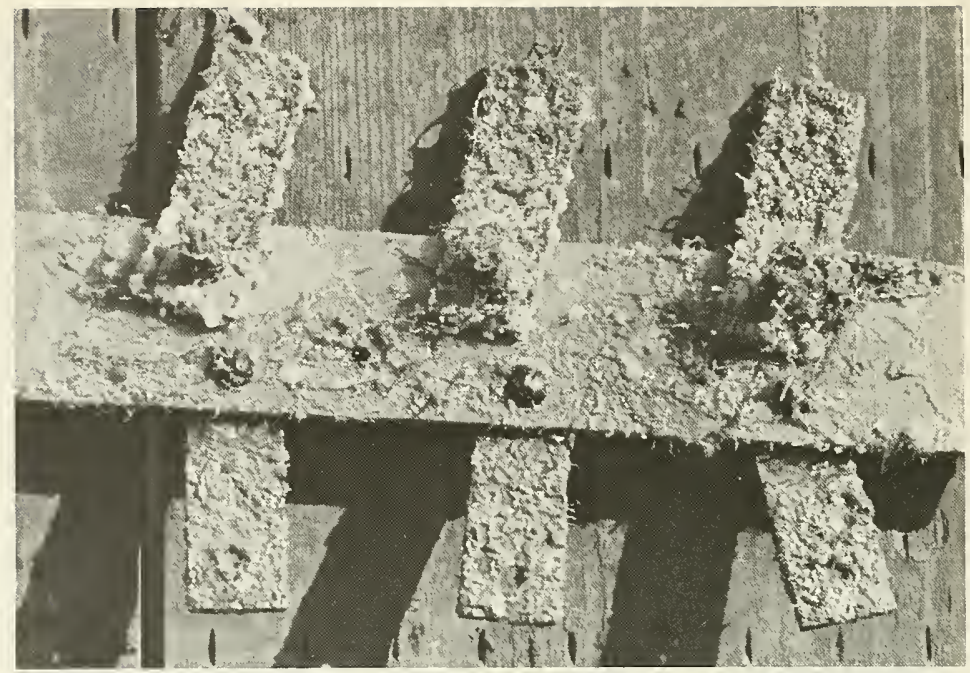

Figure 31. Marine growth and corrosion products covering the surfaces of exposed aluminum alloy (top) and steel (bottom) specimens on a plastic strip (64 days).

The effect on panels of exposure in the sea in various ways for 92 days was similar to the effect of exposure for 64 days. However, the panels (other than control panels) were covered with a larger and denser marine growth (Figure 32). Two-inch-long hydroids, 1/2-inch-diameter barnacles, and numerous $1 / 8$-inch mussels were found on the panels. Microorganisms were again isolated from inside cylinders containing control panels. During early parts of the exposure period in the sea, dense growth of Ectocarpus (brown algae) was noticed on the panels exposed for 64 and 92 days. The panels were free of other marine growth.

Seawater was found inside the nylon-screen-covered cylinders (both the 64- and the 92-day) when placed on the deck of the pier; however, as soon as the rubber stopper was removed, the seawater poured out through the screen. The screen was covered with fine silt, debris and dense marine growth. A layer of fine silt about 3/4-inch thick was found trapped at the bottom section of the cylinders. The silt was probably washed through the fine mesh screen openings during the early part of the exposure and was 
trapped inside. The bottom portion of the silt was black indicating that sulfate-reducing bacteria were present in the mud and had produced hydrogen sulfide. Although a seawater sample was not obtained for dissolved oxygen analysis, the production of hydrogen sulfide by the bacteria had no doubt occurred in an anaerobic environment; therefore, it can be assumed that there was very little oxygen present inside the fine nylon-screen-covered cylinders toward the latter part of the test. In this environment, only calcareous tubeworms were found growing on the test panels and other species of fouling organisms were absent.

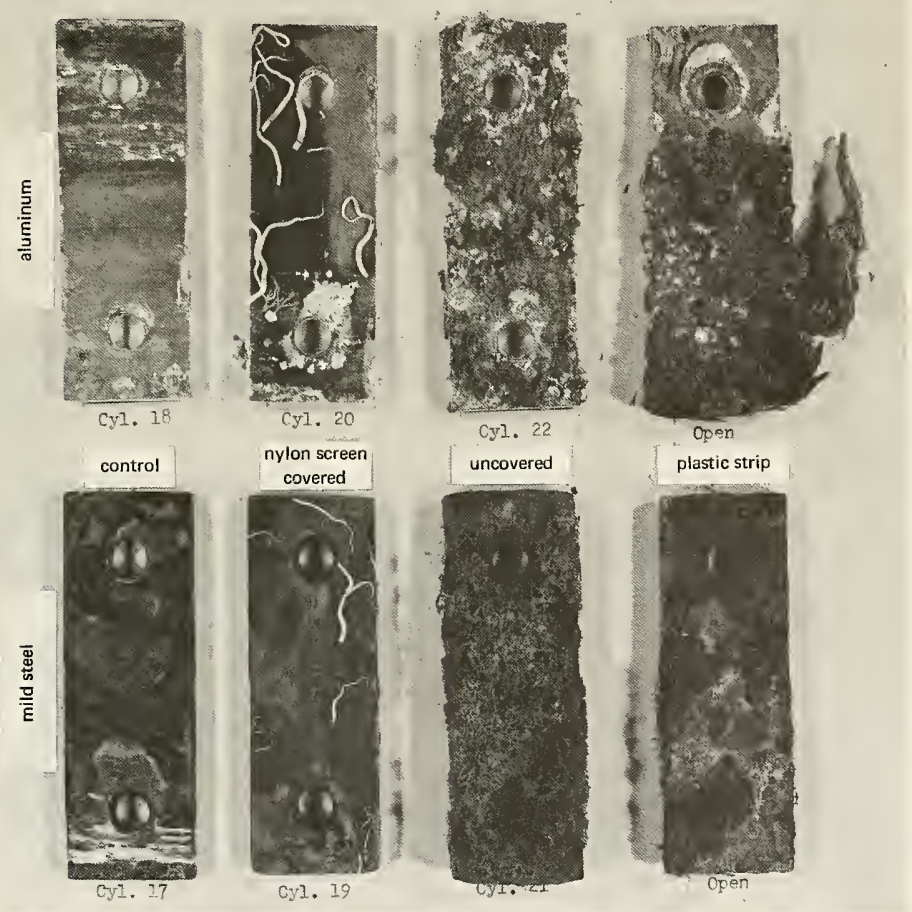

Figure 32. Marine growths and corrosion formed over test panels exposed for 92 days in different ways. Left to right: in control chamber, nylonscreen-covered chamber, uncovered chamber, and on plastic strip. 
The corrosion rates and other pertinent information on control and exposed test specimens submerged in the sea for 64 and 92 days are presented in Table 3. The information on corrosion rates is also shown graphically in Figures 33 and 34. Examination of the control and exposed panels after these were chemically cleaned showed that the panels corroded similarly to panels in Exposure Test No. 1. Since the corrosion of various metals and alloys in seawater is greatly dependent on the amount of dissolved oxygen supplied to the metal surface, seawater samples from the initially sterile test chambers sealed with membrane filters (control) and also seawater from 10 feet below the surface were collected at high tide and analyzed. The results obtained on seawater analysis are presented in Table 4. The dissolved oxygen concentration in test chambers containing control carbon steel and aluminum alloy panels was lower than in seawater collected from 10 feet below the surface at Point Mugu Pier. This could be one of the reasons for the low corrosion rate experienced by the carbon steel and aluminum alloy control panels.

Exposure Test No. 3 (23 and 43 Days). The test panels were exposed in the sea during the summer months, whereas in Exposure Test Nos. 1 and 2, the panels were exposed in the sea during the winter months. The procedure for submerging the test panels in the sea was similar to that for Exposure Test No. 2. The initially sterile test cylinders sealed with membrane filters were filled with filtered seawater in the laboratory prior to exposing them in the sea. The risk of rupturing the thin membrane filter is reduced using this method.

When the carbon steel and aluminum alloy exposed panels were recovered and examined, the panels were covered primarily with a very light growth of hydroids, and branching and encrusting bryozoans. Only a trace of Ectocarpus (brown algae) growth was present on these panels. The control panels were free of marine growth. However, microorganisms were again found in seawater samples containing the control panels inside cylindrical chambers sealed with membrane filters. The morphology of these bacteria was similar to that of the bacteria found in previous exposure tests. The effect of these microorganisms on corrosion rates is not known. The dissolved oxygen concentration of the seawater in which the control panels were exposed was low compared to the concentration in the seawater samples collected 10 feet below the surface of the sea at Point Mugu Pier. Other pertinent information on the seawater environment is presented in Table 4. Such information is helpful in evaluating corrosion rates of test panels which were exposed in the sea under varying conditions. 


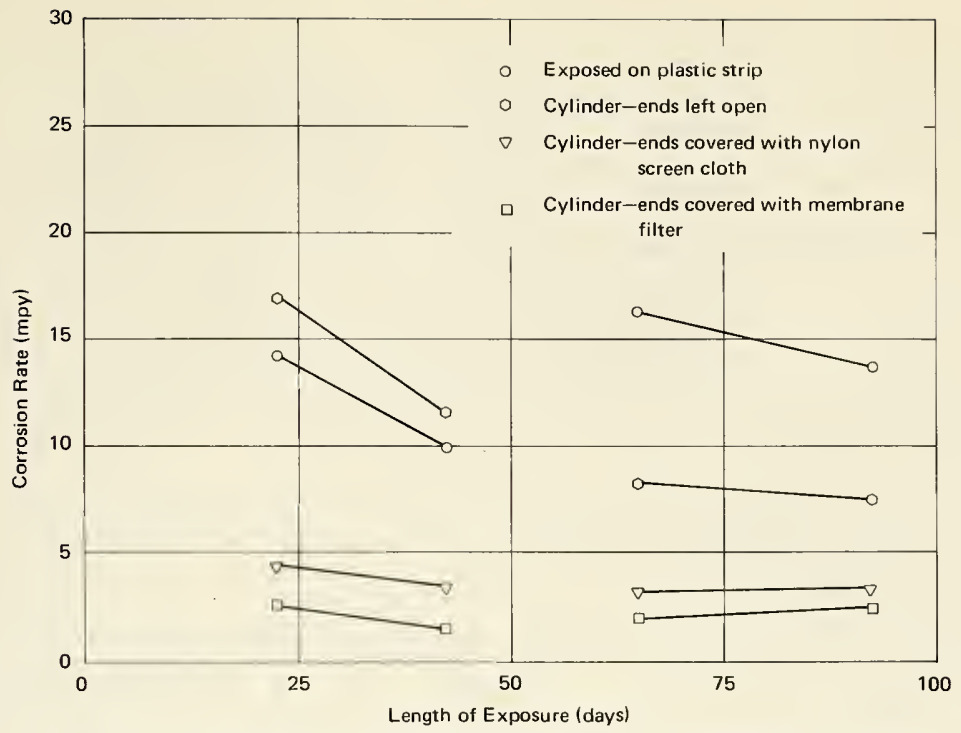

Figure 33. Corrosion rates of 1010 carbon steel near ocean surface after $23,43,64$, and 92 days under various conditions.

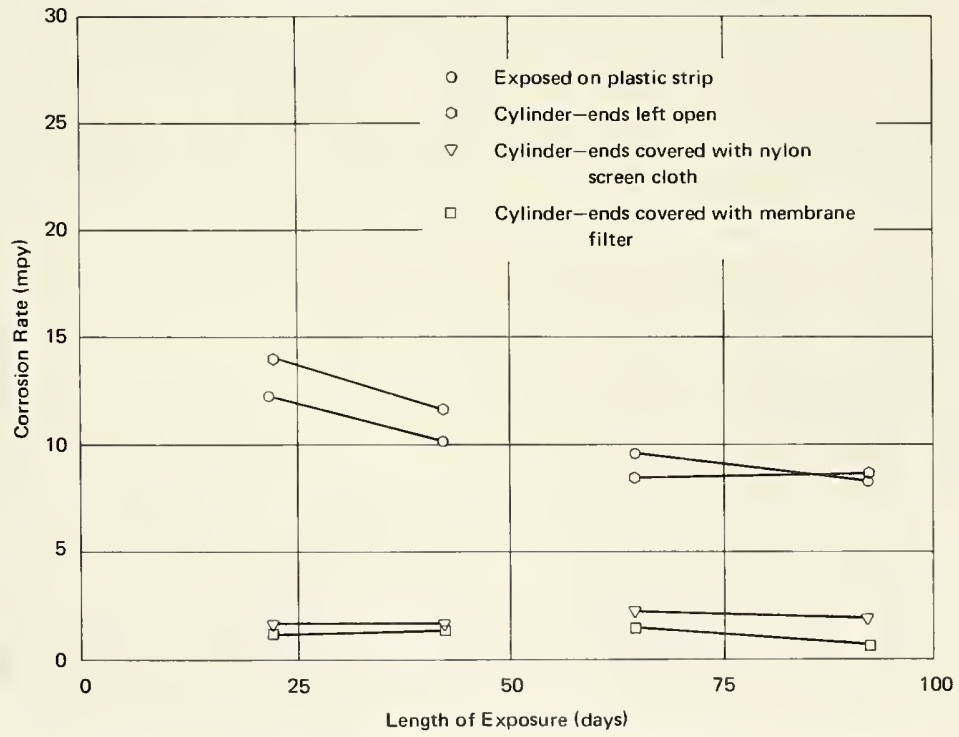

Figure 34. Corrosion rates of 7178-T6 aluminum alloy near ocean surface after $23,43,64$, and 92 days under various conditions. 


\begin{tabular}{|c|c|c|c|c|c|c|}
\hline & \multicolumn{2}{|l|}{ 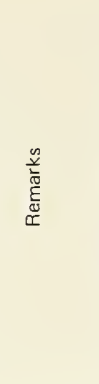 } & 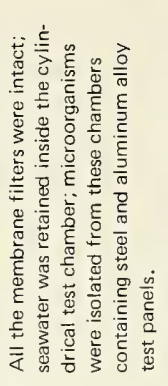 & 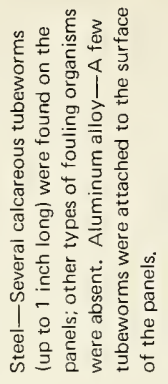 & 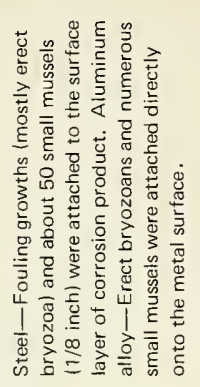 & 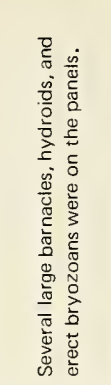 \\
\hline \multirow{4}{*}{ 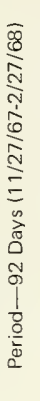 } & \multirow{2}{*}{ 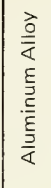 } & $\frac{\grave{a}}{\Sigma}$ & $\stackrel{N}{\stackrel{N}{0}}$ & $\stackrel{5}{-}$ & $\begin{array}{l}8 \\
\infty \\
\infty\end{array}$ & $\underset{\infty}{\stackrel{m}{\infty}}$ \\
\hline & & $\begin{array}{l}\stackrel{0}{\Sigma} \\
\stackrel{2}{\Sigma}\end{array}$ & $\underset{\check{\beth}}{-}$ & $\begin{array}{l}\hat{\omega} \\
\stackrel{m}{ }\end{array}$ & 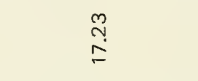 & $\begin{array}{l}f \\
\triangleq\end{array}$ \\
\hline & \multirow{2}{*}{$\begin{array}{l}\bar{\Phi} \\
\dot{\Phi} \\
\dot{s}\end{array}$} & $\frac{\grave{2}}{\Sigma}$ & 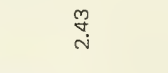 & $\begin{array}{l}\text { ले } \\
\text {. }\end{array}$ & 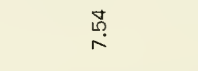 & $\begin{array}{l}\stackrel{L}{0} \\
\stackrel{\leftrightarrow}{\sim}\end{array}$ \\
\hline & & $\frac{O}{\stackrel{\partial}{\Sigma}}$ & $\stackrel{m}{\stackrel{m}{m}}$ & $\stackrel{\llcorner}{\infty} \underset{\sim}{\infty}$ & $\frac{N}{\dot{J}}$ & $\stackrel{\varphi}{\dot{\sim}}$ \\
\hline \multirow{4}{*}{ 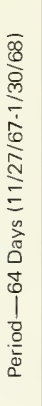 } & \multirow{2}{*}{ 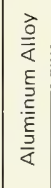 } & $\stackrel{\succ}{\grave{\Sigma}}$ & $\stackrel{\text { m̆ }}{-}$ & 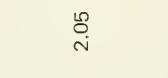 & $\begin{array}{l}8 \\
\infty \\
\infty\end{array}$ & $\frac{\infty}{\vdots}$ \\
\hline & & $\stackrel{\circ}{\Sigma}$ & $\stackrel{\leftrightarrow}{\mathrm{N}}$ & $\stackrel{\circ}{\stackrel{\leftrightarrow}{+}}$ & $\begin{array}{l}\infty \\
\stackrel{\infty}{\circ}\end{array}$ & $\begin{array}{l}\stackrel{\sigma}{\infty} \\
\stackrel{-}{\circ}\end{array}$ \\
\hline & \multirow{2}{*}{$\begin{array}{l}\bar{\Phi} \\
\text { 心 }\end{array}$} & 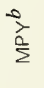 & $\underset{\text { ì }}{\text { in }}$ & $\stackrel{\bar{m}}{\bar{m}}$ & $\begin{array}{c}\bar{m} \\
\infty\end{array}$ & $\begin{array}{l}\stackrel{g}{+} \\
\stackrel{6}{0}\end{array}$ \\
\hline & & $\stackrel{0}{\Sigma}$ & $\stackrel{\stackrel{T}{=}}{=}$ & $\stackrel{m}{=}$ & サே & вं \\
\hline & 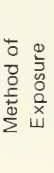 & & 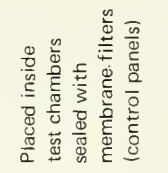 & 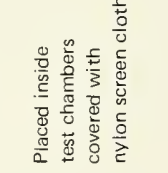 & 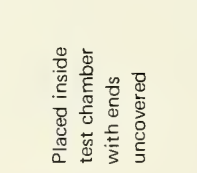 & 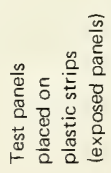 \\
\hline
\end{tabular}




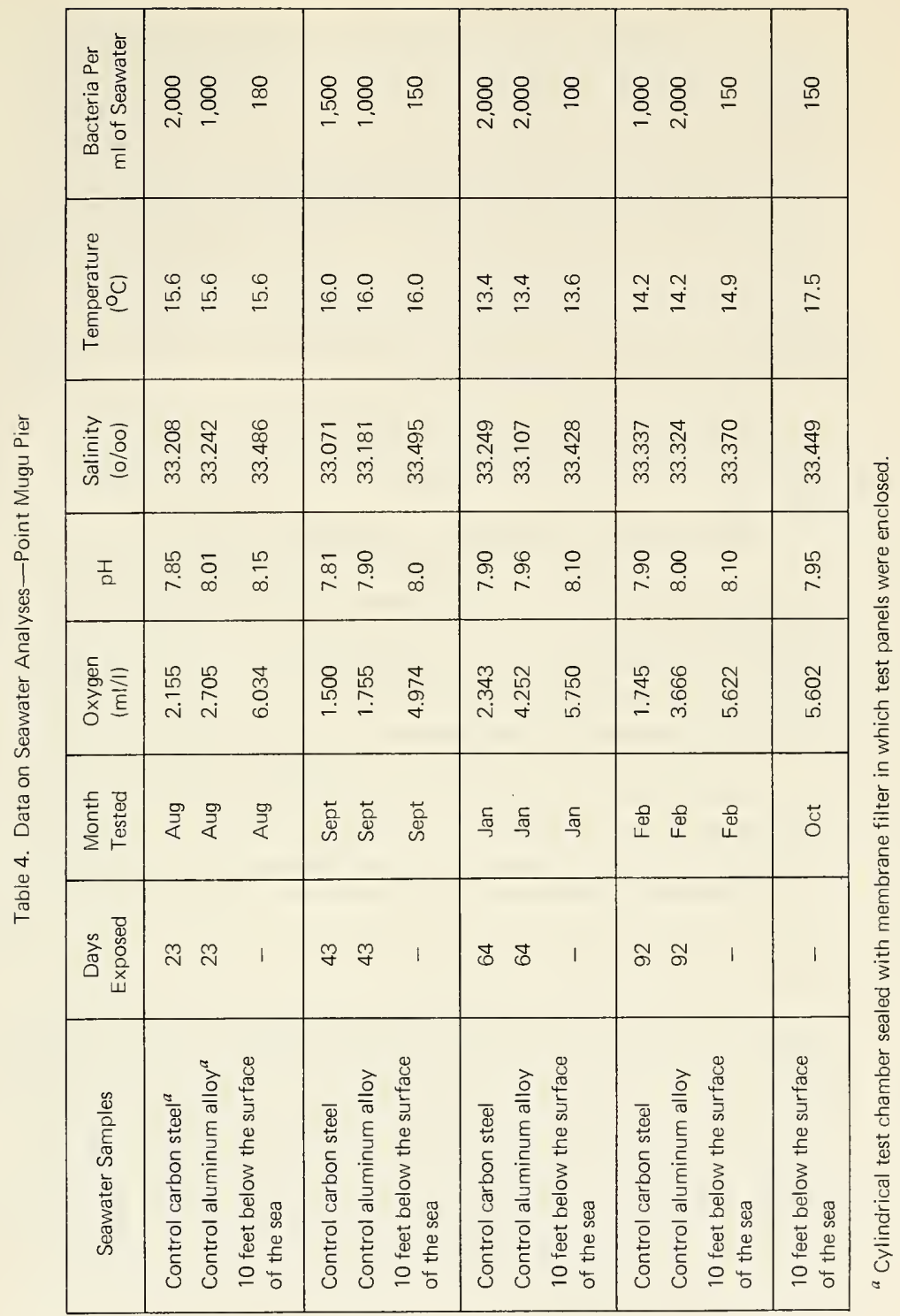


During recovery of the cylinders covered with nylon screen after 23 days of immersion, the seawater flowed out. However, seawater was retained inside those cylinders which were exposed for 43 days. The screen was covered with marine growth, silt, and fine detritus. Inside the cylinders exposed for 23 and 43 days, about a 3/4-inch-thick layer of fine silt was found trapped at the bottom. The bottom portion of the fine, gray silt had turned black, indicating that hydrogen sulfide was being produced by sulfatereducing bacteria in an anaerobic environment. The presence of sulfate-reducing bacteria in the sediment samples was confirmed by bacteriological tests using a nutrient medium employed by Morita and ZoBell. ${ }^{12}$ Only a small number of calcareous tubeworms were found growing on the surface of these test panels. Other varieties of marine animals were absent.

The corrosion rates of the 23- and 43-day panels are presented in Table 5 and are shown graphically in Figures 33 and 34 . Information on weight losses incurred by individual panels during this period is presented in Table 6.

The corrosion rates of carbon steel and aluminum alloy test specimens for the three exposure tests have been combined and are shown graphically in Figures 35 and 36. The corrosion rates for both carbon steel and aluminum alloy panels exposed in cylinders covered with (1) nylon screen, and (2) in cylinders with ends left open have been extrapolated for the period between 92 days and 268 days of exposure. Exposure tests under these conditions were not conducted during these periods.

In general the steel and aluminum alloy test panels which were directly exposed to various destructive agents of the ocean environment including marine fouling organisms corroded at a much faster rate than those test panels which were protected inside cylindrical chambers.

Some other factors which affect and control corrosion besides marine fouling organisms (barnacles, hydroids, bryozoans, mussels and microorganisms) and their metabolic and decay products are:

1. Dissolved oxygen concentration. The corrosion rate of steel in seawater is affected by the amount of oxygen supplied to the metal surfaces. ${ }^{13,14}$ After prolonged exposure, the carbon steel starts to produce and accumulates a thick layer of rust which protects the underlying metal surfaces from coming in contact with fresh seawater. The corrosion rates of such panels approach constancy after extended exposure as shown in Figure 35. The fouling organisms are usually attached to the layer of rust over the metal surfaces and their foothold on these steel panels depends upon the adhesion of the corrosion products to the metal surfaces. Aluminum alloys, on the other hand, are usually protected by dissolved oxygen which aids in the formation of a thin 
protective coating over the surfaces by oxidation. As shown in Figure 36, corrosion rates for aluminum also approch constancy after extended exposure. Since aluminum alloys do not produce a uniform layer of thick corrosion products over the surface, marine fouling growth, especially barnacles, become firmly attached directly onto the surfaces and are very difficult to remove (Figure 22). Certain types of fouling attachment may even protect metal alloys from corrosion. On the other hand, crevice corrosion does occur underneath barnacle shells attached to certain stainless steel and monel panels. 5,6

2. High current velocities. These cause corrosion by removing loose corrosion products and replenishing the cleaned steel surfaces with dissolved oxygen thereby increasing corrosion more rapidly. The effect of tidal currents on the corrosion rates of test panels exposed at the surface was inconclusive as shown in Figures 33 and 34

3. Temperature. In general, the effect of temperature on the corrosion rate depends on its influence on the factors controlling the corrosion reaction. ${ }^{13}$ The corrosion rates of test panels exposed at the surface were not significantly influenced by changes in water temperature at Point Mugu Pier.

In addition to the various factors mentioned above which control corrosion, a dense growth of Ectocarpus (brown algae) may also have affected the corrosion rates by producing and concentrating a microlayer of dissolved oxygen over the surfaces of test panels during the early exposure period. A dense growth of Ectocarpus was found on panels which were exposed in the sea during the winter. However, such dense growth was not detected on panels exposed during the summer.

The combined effects of dense marine growth, high dissolved oxygen concentration, current velocities and water temperatures play a significant role in promoting corrosion in the sea.

The effect of marine fouling on corrosion rates of test panels in the sea (surface) was not definitely established by the experimental methods used in this current study because (1) bacteria were found inside initially sterile cylindrical chambers containing control panels and their effect on corrosion is not known; and (2) the control and exposed panels were not subjected to identical concentration of dissolved oxygen nor to identical current velocities because deposits of fine silt, debris, and biological growth over the membrane filter prevented the free exchange of fresh seawater between the two environments. It is not definitely known whether the lower corrosion rates experienced by control panels inside the chambers sealed with membrane filters were caused by low dissolved oxygen content or by lack of marine growth. 


\begin{tabular}{|c|c|c|c|c|c|}
\hline & \multicolumn{2}{|l|}{ 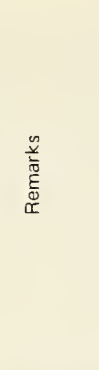 } & 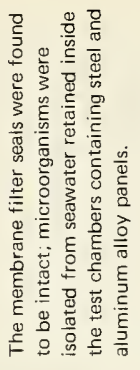 & 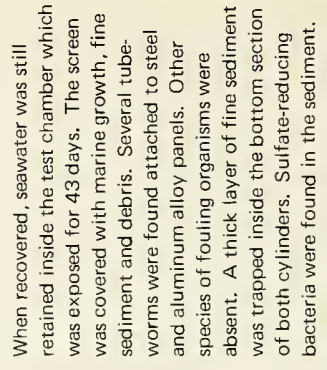 & 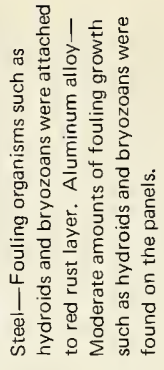 \\
\hline \multirow{4}{*}{ 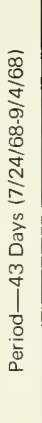 } & \multirow{2}{*}{ 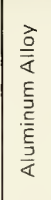 } & 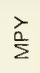 & 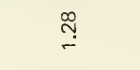 & $\stackrel{I}{\ddagger}$ & $\stackrel{ }{=}$ \\
\hline & & 号 & 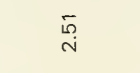 & 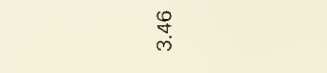 & $\stackrel{\text { లె }}{\text { Dे }}$ \\
\hline & \multirow{2}{*}{$\begin{array}{l}\overline{\bar{g}} \\
\text { is }\end{array}$} & $\stackrel{\succsim}{\sum^{2}}$ & مִ & ने & $\stackrel{ }{=}$ \\
\hline & & $\frac{0}{2}$ & $\underset{\infty}{\stackrel{N}{ }}$ & $\stackrel{\circ}{\circ}$ & $\begin{array}{l}\hat{m} \\
\text { ङे }\end{array}$ \\
\hline \multirow{2}{*}{ 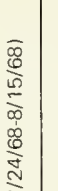 } & \multirow{2}{*}{ 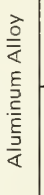 } & $\stackrel{\succ}{\Sigma}$ & 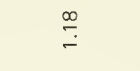 & $\stackrel{m}{=}$ & 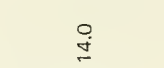 \\
\hline & & $\stackrel{\circ}{\Sigma}$ & ָூ & ल्ల్ & 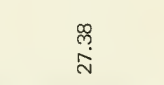 \\
\hline \multirow{2}{*}{ 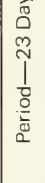 } & \multirow{2}{*}{$\begin{array}{l}\bar{\Phi} \\
\text { w } \\
\dot{\omega}\end{array}$} & $\begin{array}{l}\infty \\
\grave{\Sigma} \\
\dot{\Sigma}\end{array}$ & 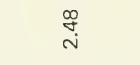 & 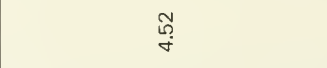 & 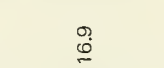 \\
\hline & & $\begin{array}{l}\text { : } \\
\stackrel{\circ}{\Sigma}\end{array}$ & $\begin{array}{l}\stackrel{\varphi}{\dot{m}} \\
\stackrel{-}{2}\end{array}$ & $\stackrel{\infty}{\stackrel{d}{\sim}}$ & $\begin{array}{l}\text { ల్ } \\
\text { } \\
\delta\end{array}$ \\
\hline & 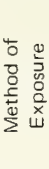 & & 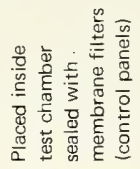 & 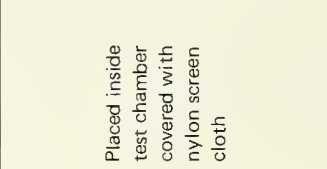 & 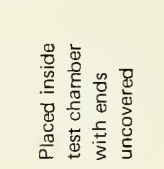 \\
\hline
\end{tabular}




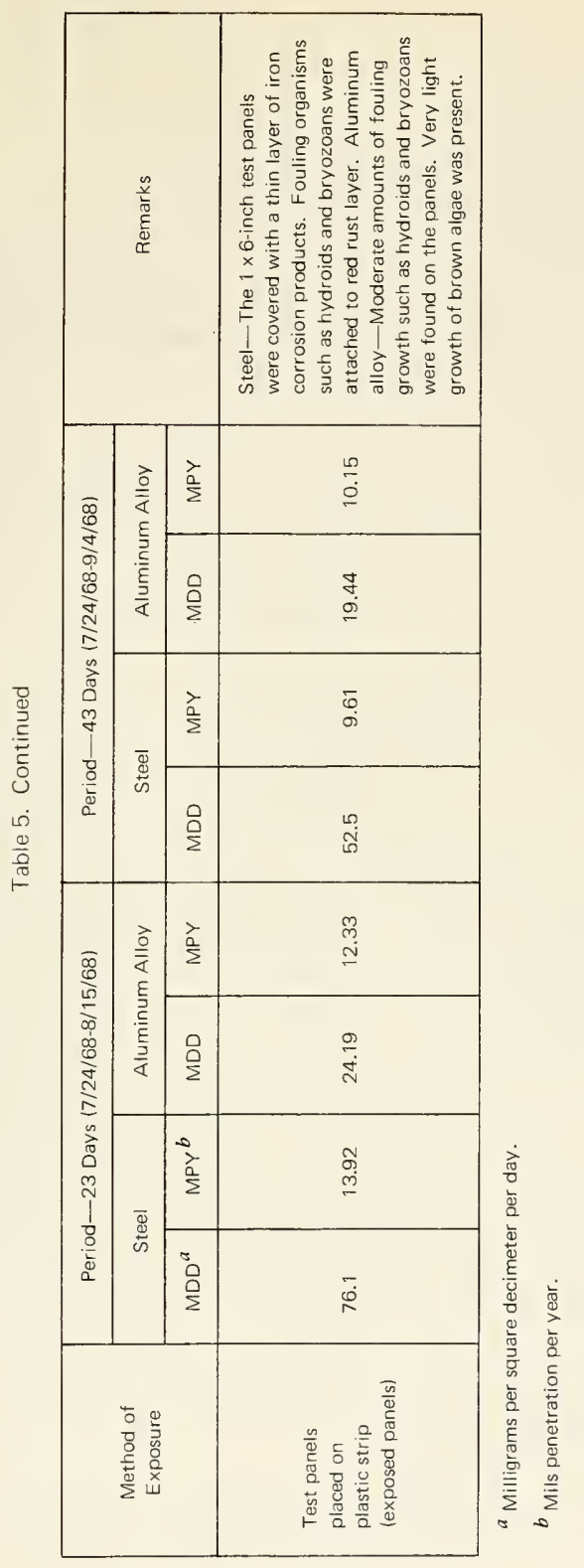


Table 6. Weight Loss Incurred by Each Test Panel ${ }^{a}$

\begin{tabular}{|c|c|c|c|}
\hline \multirow{2}{*}{ Method of Exposure } & \multirow{2}{*}{ Test Panels } & \multicolumn{2}{|c|}{ Weight Loss (gm) for- } \\
\hline & & 23 Days' Exposure & 43 Days' Exposure \\
\hline \multicolumn{4}{|c|}{ Carbon Steel } \\
\hline $\begin{array}{l}\text { Control in initially sterile } \\
\text { cylinder covered with a } \\
\text { membrane filter }\end{array}$ & $\begin{array}{l}1 \\
2\end{array}$ & $\begin{array}{l}0.1338 \\
0.1338\end{array}$ & $\begin{array}{l}0.1539 \\
0.1472\end{array}$ \\
\hline $\begin{array}{l}\text { Placed inside cylinder with } \\
\text { ends covered with nylon screen }\end{array}$ & $\begin{array}{l}1 \\
2\end{array}$ & $\begin{array}{l}0.2603 \\
0.2315\end{array}$ & $\begin{array}{l}0.4006 \\
0.3020\end{array}$ \\
\hline $\begin{array}{l}\text { Placed inside cylinder with } \\
\text { ends left open }\end{array}$ & $\begin{array}{l}1 \\
2\end{array}$ & $\begin{array}{l}1.0204 \\
0.8707\end{array}$ & $\begin{array}{l}1.2752 \\
1.0997\end{array}$ \\
\hline Exposed on plastic strip & $\begin{array}{l}1 \\
2\end{array}$ & $\begin{array}{l}1.5545^{b} \\
1.5546^{b}\end{array}$ & $\begin{array}{l}1.9617^{b} \\
1.0190^{a}\end{array}$ \\
\hline \multicolumn{4}{|c|}{ Aluminum Alloy } \\
\hline $\begin{array}{l}\text { Control in initially sterile } \\
\text { cylinder covered with a } \\
\text { membrane filter }\end{array}$ & $\begin{array}{l}1 \\
2\end{array}$ & $\begin{array}{l}0.0224 \\
0.0233\end{array}$ & $\begin{array}{l}0.0484 \\
0.0553\end{array}$ \\
\hline $\begin{array}{l}\text { Placed inside cylinders with } \\
\text { ends covered with nylon } \\
\text { screen }\end{array}$ & $\begin{array}{l}1 \\
2\end{array}$ & $\begin{array}{l}0.0329 \\
0.0346\end{array}$ & $\begin{array}{l}0.0565 \\
0.0741\end{array}$ \\
\hline $\begin{array}{l}\text { Placed inside cylinders with } \\
\text { ends left open }\end{array}$ & $\begin{array}{l}1 \\
2\end{array}$ & $\begin{array}{l}0.2951 \\
0.2501\end{array}$ & $\begin{array}{c}0.4195 \\
-\end{array}$ \\
\hline Exposed on plastic strip & $\begin{array}{l}1 \\
2\end{array}$ & $\begin{array}{l}0.5300^{b} \\
0.4764^{b}\end{array}$ & $\begin{array}{l}0.7783^{b} \\
0.7307^{b}\end{array}$ \\
\hline
\end{tabular}

a Specimen dimensions: $1 \times 3$ inches.

$b$ Specimen dimensions: $1 \times 6$ inches. 


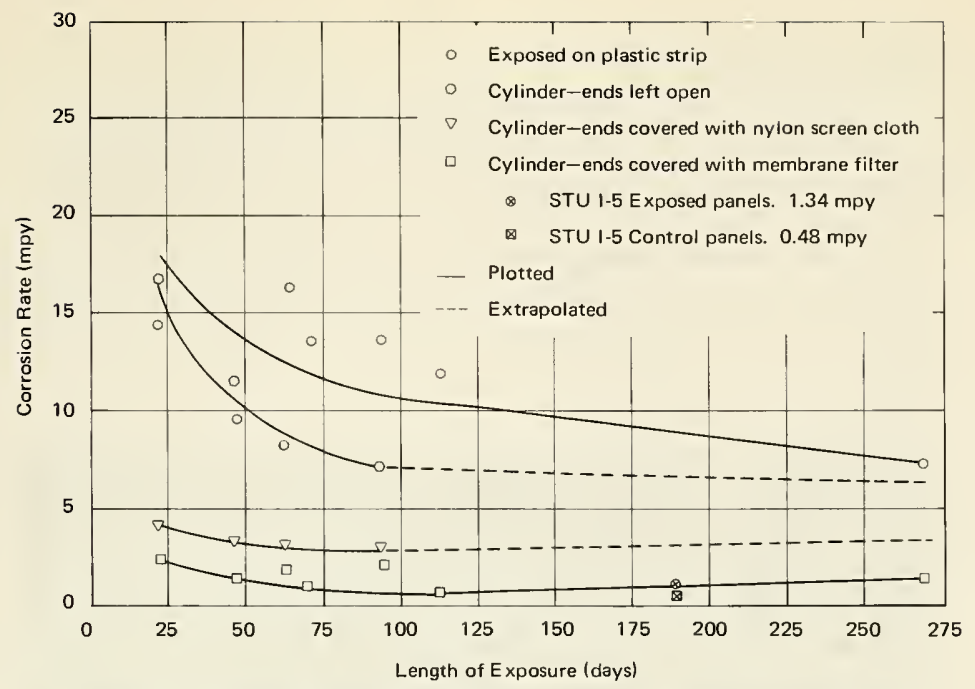

Figure 35. Corrosion rates of 1010 carbon steel near ocean surface from data presented in Tabies 2, 3, and 5 .

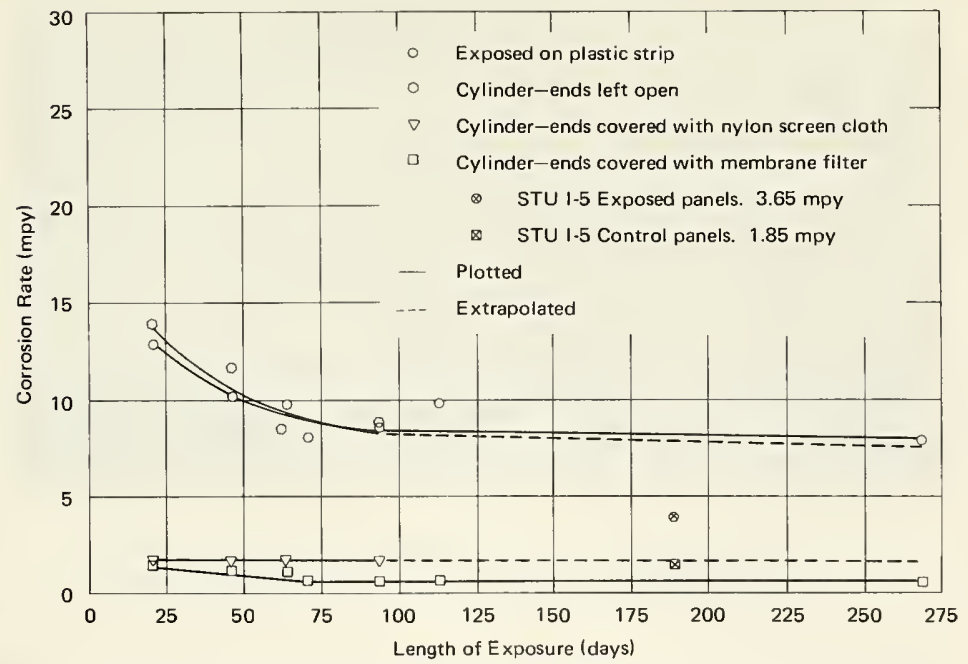

Figure 36. Corrosion rates of 7178-T6 aluminum alloy near ocean surface from data presented in Tables 2, 3, and 5. 


\section{Deep-Ocean Exposure Test}

Identical test specimens which were immersed at the surface at Point Mugu Pier were also exposed in the deep-ocean environment to compare biological corrosion rates. Only exposed and control test specimens were placed on STU 1-5, ${ }^{*}$ which was emplaced on the seafloor in 6,000 feet of water for a period of 189 days (6.3 months) in the Pacific Ocean (Figure 37). The test site is located about 80 miles southwest of Port Hueneme, California. The initially sterile cylindrical test chambers containing control panels were filled with surface seawater $\left(5.6 \mathrm{ml} / /\right.$ of $\left.\mathrm{O}_{2}\right)$ aboard ship prior to exposure in the deep sea.

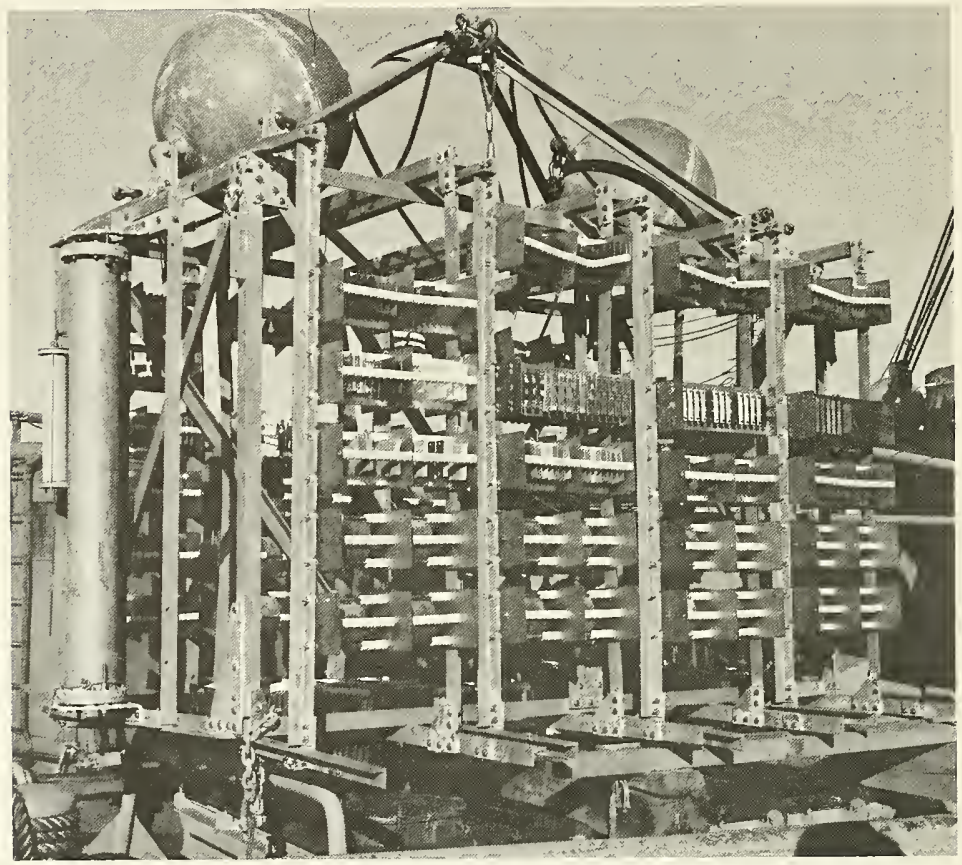

Figure 37. STU 1-5 structure with test specimens on deck of a ship. The STU was emplaced on the seafloor at a depth of 6,000 feet for a period of 6.3 months.

\footnotetext{
* Supported principally by Work Unit No. YF 38.005.01.008.
} 
As soon as the STU structure was recovered from the sea and placed on the deck of the ship, the two test chambers containing control steel and aluminum alloy specimens were removed from the STU and water samples carefully collected from inside each chamber. The water samples were treated in different ways as follows:

1. "Pickled" immediately with manganous sulfate solution and alkaline potassium iodide solution so that dissolved oxygen concentration could be determined later in the laboratory.

2. About $10 \mathrm{ml}$ of seawater was collected aseptically using sterile syringe for bacteriological tests and stored in the ship's refrigerator for later evaluation.

3. Water temperature and $\mathrm{pH}$ values were determined immediately aboard ship.

4. Water samples were stored in glass containers for determination of salinity at the laboratory.

The results of these tests are presented in Table 7. Seawater samples had been collected from a depth of 6,000 feet near the seafloor in the vicinity of the STU exposure site during previous oceanographic data collection cruises. The seawater analyses of these deep-ocean water samples were conducted aboard ship and the results obtained are presented in Table 7.

As shown in Table 7, the dissolved oxygen concentration inside the cylindrical test chamber in which control panels were exposed was slightly higher than that in seawater samples collected at the seafloor in 6,000 feet of water. A small number of microorganisms (200/ml) were again found in seawater containing control panels. The microorganisms could be species of cellulose-decomposing marine bacteria. If so, these bacteria could have penetrated the membrane filter which is made of cellulose ester. The effects of these bacteria on corrosion of control panels is not known.

When the exposed steel and aluminum alloy specimens were examined immediately after recovery aboard ship, the test panels were found to be free of any fouling organisms, except for bacterial slime growth. The steel panels were covered with a moderately thick layer of red rust (Figure 38). When a small section of this red rust was removed, a bright metal surface was found underneath. The aluminum alloy panels, especially along the edges and ends, were covered with large masses of white aluminum oxide corrosion products (Figure 39). The flat surface area was relatively free of such corrosion products.

The steel and aluminum alloy control panels which were protected inside the cylindrical test chambers were relatively free of corrosion products on their surfaces (Figure 40). 


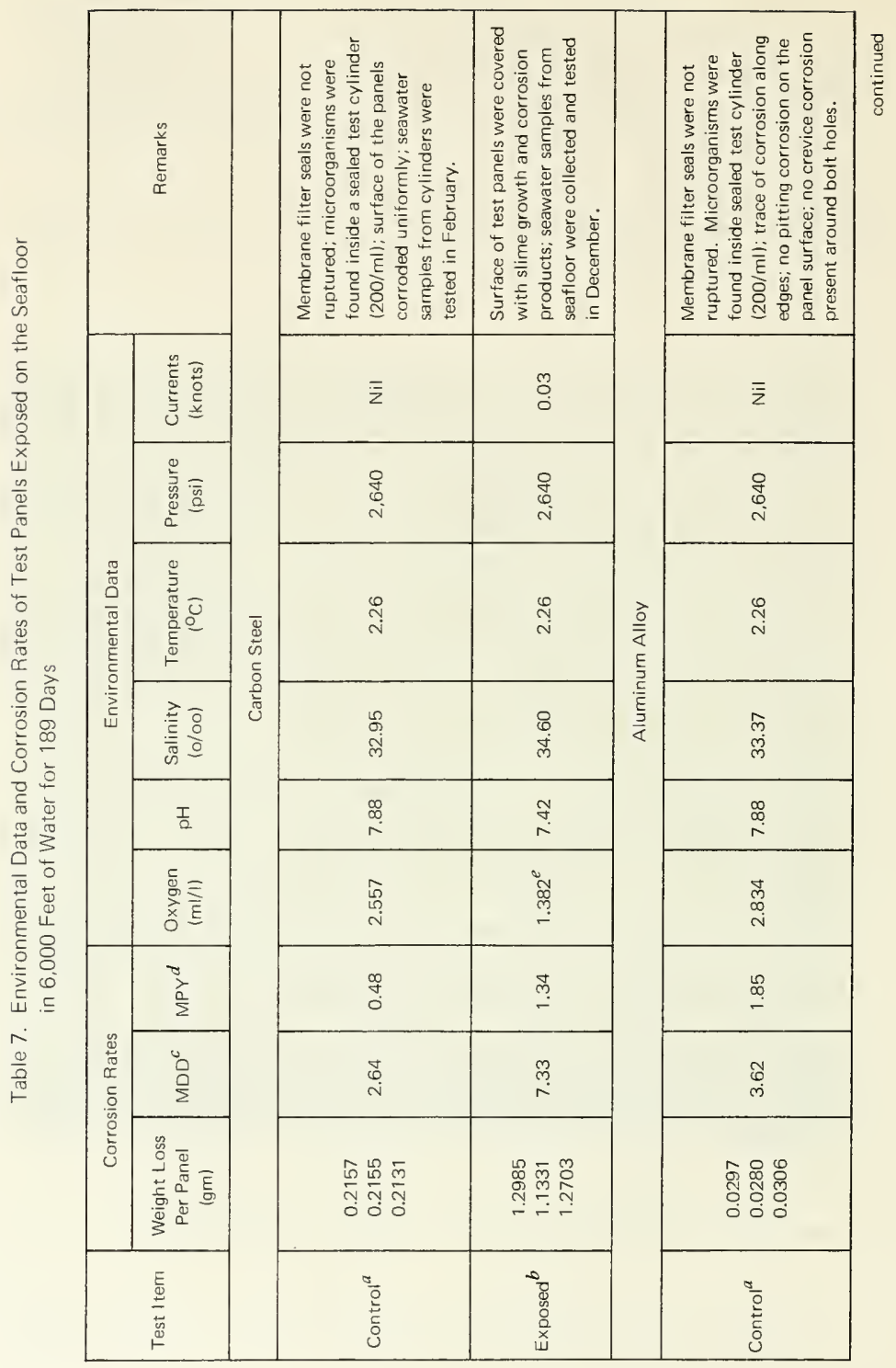




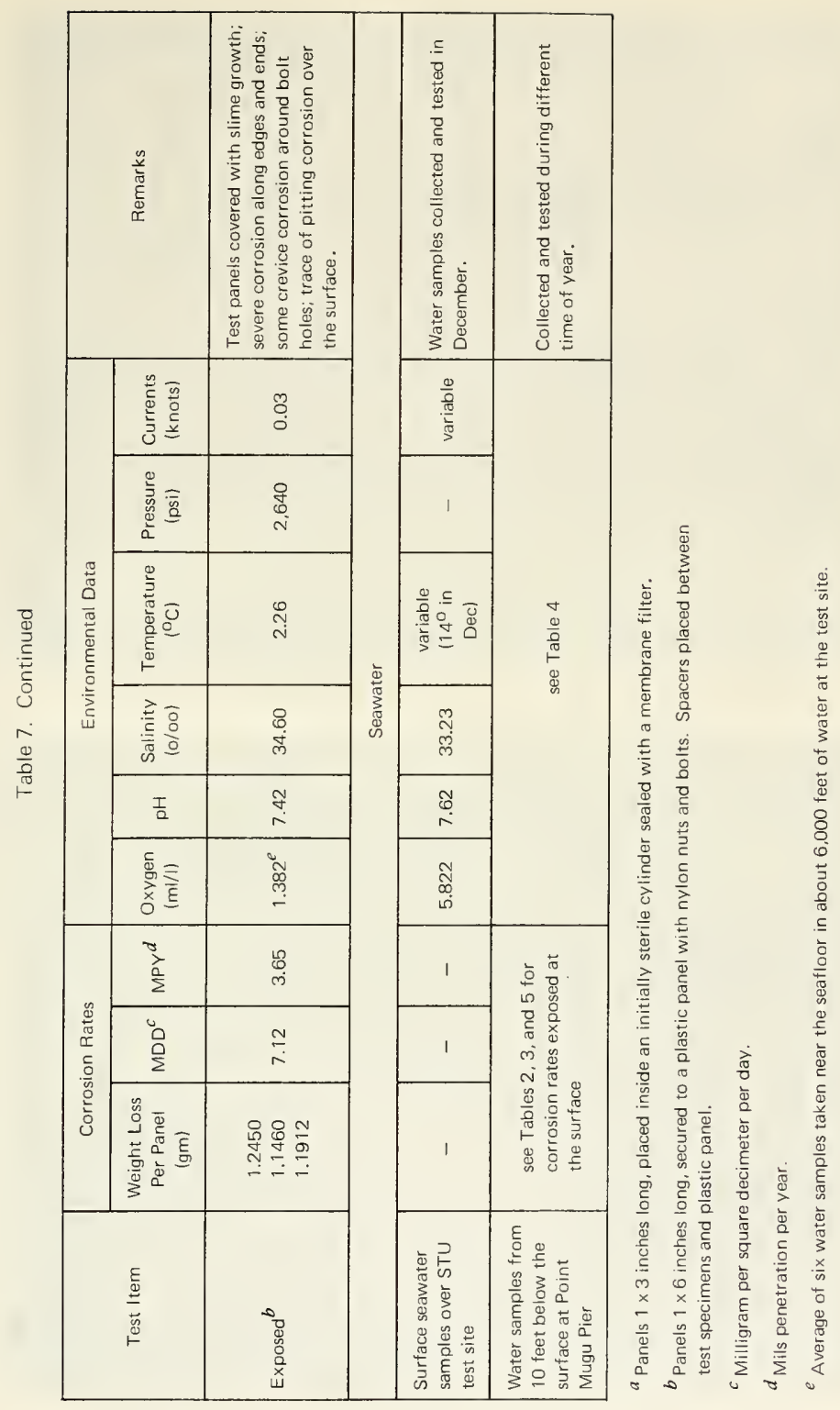




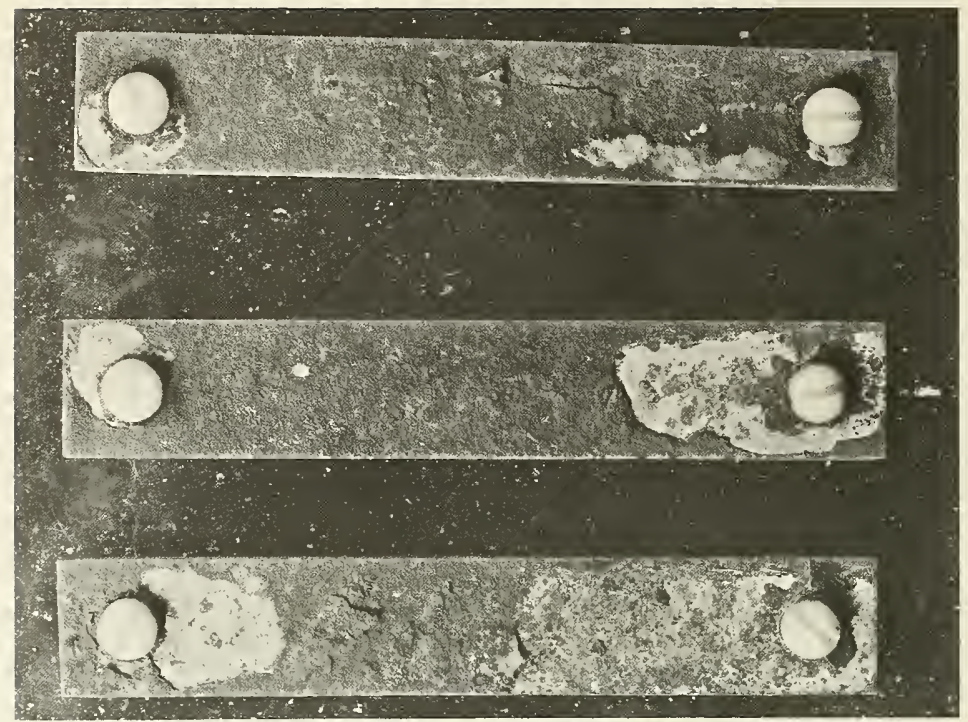

Figure 38. Exposed carbon steel specimens uniformly covered with a layer of red rust. Exposed on STU 1-5.

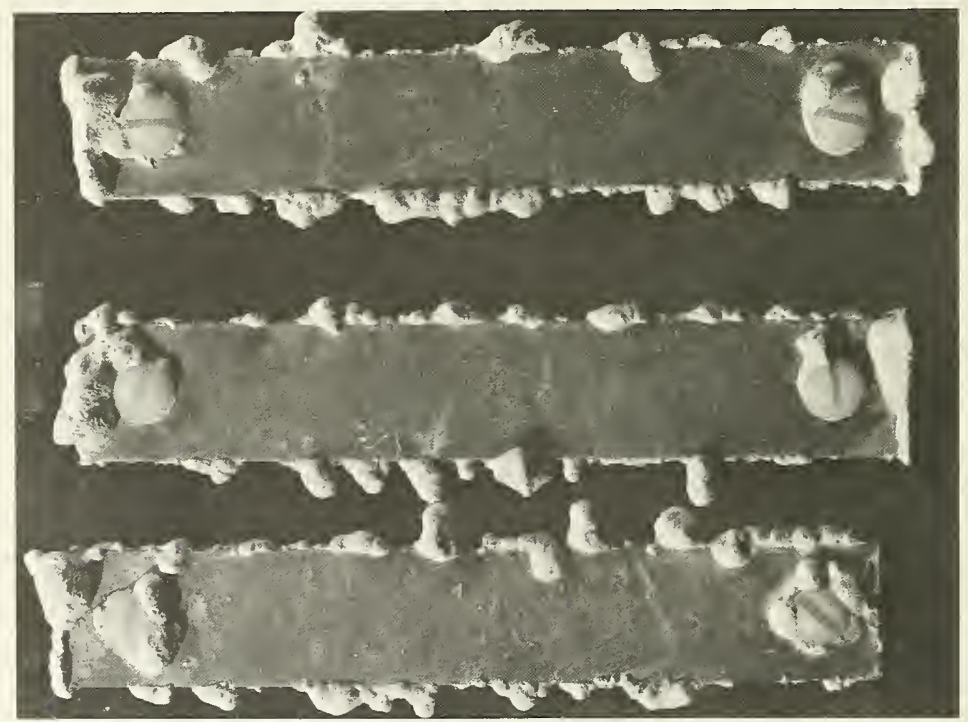

Figure 39. Exposed aluminum alloy panels; large amounts of white corrosion product had formed along the edges. Exposed on STU I-5. 


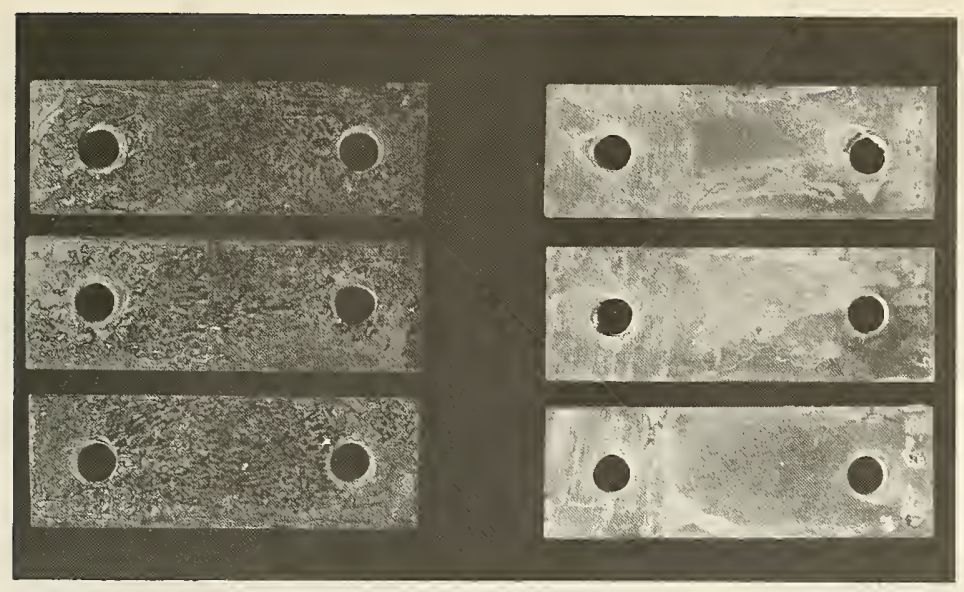

Figure 40. Carbon steel and aluminum alloy control panels which were placed inside initially sterile cylindrical chambers sealed with membrane filters were relatively free of corrosion products.

Examination of the exposed aluminum alloy panels after chemical cleaning revealed that the edges and ends of these panels were severely corroded (Figure 41). Crevice corrosion was also found around the holes underneath the nylon nuts and bolts. Only a trace of pitting corrosion had occurred over the surface area of the aluminum alloy panels. The exposed steel panels corroded uniformly without formation of any pits or any crevice corrosion on their surfaces. The control aluminum alloy panels were free of pitting corrosion on the surface and crevice corrosion around the bolt holes; however, there were traces of light corrosion along the edges and ends of these panels. The control steel panels corroded uniformly (Figures 41 and 42). The corrosion rates of 1010 carbon steel and 7178-T6 aluminum alloy panels which had been exposed on the seafloor in 6,000 feet of water for a period of 189 days are presented in Table 7 . This information is also plotted on Figures 35 and 36 so that the rates of biological corrosion which occurred at the surface and at depth can be compared. The data presented in Table 7 , and Figures 35 and 36 show that bacterial slime growth and metabolic products may have played a significant role in accelerating corrosion on the deep ocean floor. The corrosion rates for exposed carbon steel panels which were 


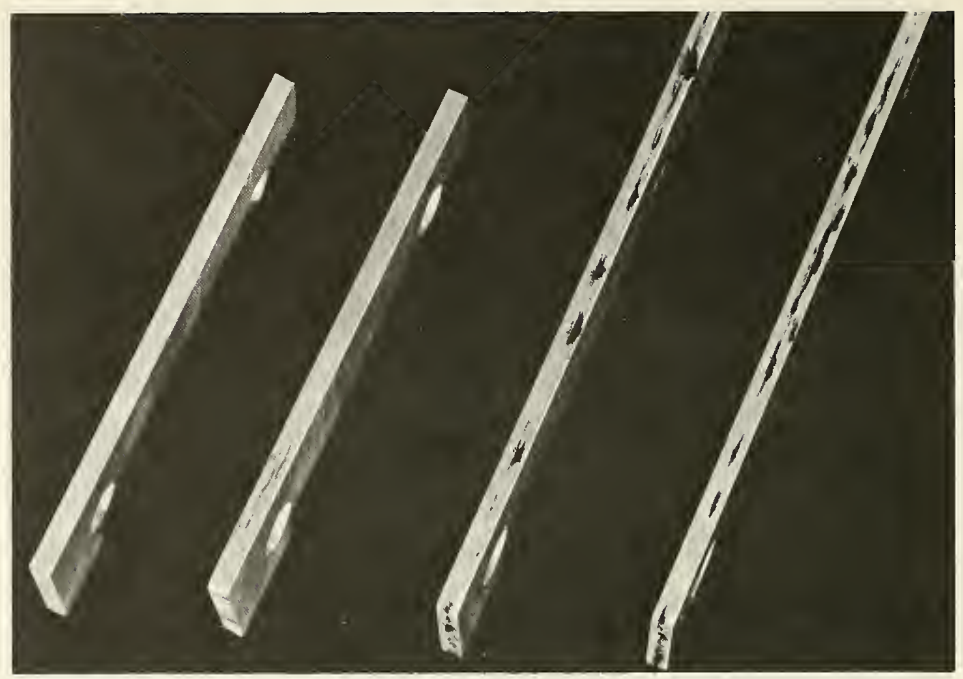

Figure 41. Chemically cleaned aluminum alloy panels; pockets of deep corrosion had formed along the edges and ends of exposed panels (right). Such corrosion was absent from control panels (left).

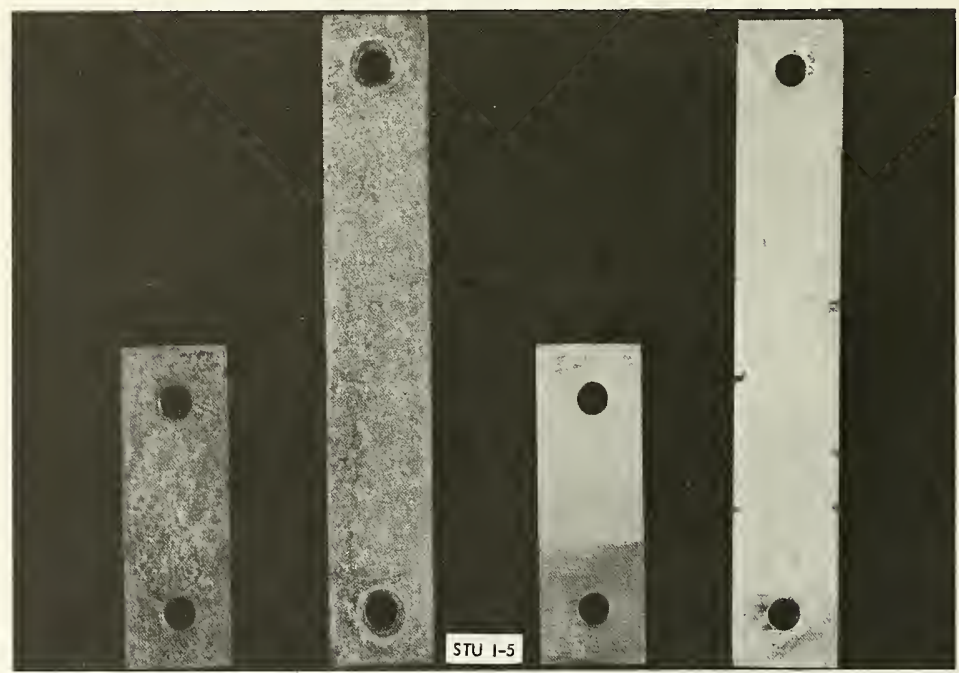

Figure 42. Chemically cleaned surfaces of carbon steel (left) and aluminum alloy (right) panels. Steel-Surfaces of both control and exposed panels corroded uniformly. Aluminum-Crevice and pitting corrosion were absent over control (short) panels. Crevice corrosion around bolt holes and trace of pitting corrosion were present over exposed (long) panel. 
subjected to deep-ocean bacterial slime growth were slightly higher than for the control panels exposed at the surface of the sea. The slime-covered exposed aluminum alloy panels which were placed near the deep-ocean floor also corroded at a higher rate than the control panels which were exposed both at the surface and in the deep ocean, with low dissolved oxygen concentration present in all three cases.

On the deep-ocean floor where the concentration of dissolved oxygen is low, the exposed aluminum panels corroded at a faster rate than the exposed carbon steel panels (Figures 35 and 36 ).

\section{Corrosion Rates-Surface Versus Deep-Ocean}

At the surface, materials submerged in the sea soon become heavily fouled with animal and plant growth. The principal fouling animals are barnacles, microorganisms, tunicates, hydroids, mussels, tubeworms, and bryozoans; the principal plants are algae and kelp. In the deep-ocean environment, it has been found that a large number of bacteria inhabit the sediment, and these microorganisms have destroyed test samples of organic materials placed on the seafloor. These microorganisms also form heavy slime coatings over the surfaces of metallic as well as nonmetallic materials placed on the seafloor. It has also been found that attachment of other fouling organisms on materials at great depth is minimal. However, there are many marine wood boring molluscs present, even at depths of 6,800 feet, and these borers have destroyed untreated wood test specimens within a very short period. ${ }^{15,16,17,18}$

As shown in Tables 4 and 7 , the seawater environment at the surface of the sea is considerably different from that at great depths. The corrosion rates of carbon steel and aluminum alloy test panels have varied significantly when panels have been placed in these different environments.

After 189 days in the sea, the corrosion rate of exposed 1010 carbon steel panels exposed at the surface of the sea was $8.5 \mathrm{mpy}$ (estimated from Figure 35) as compared to 1.34 mpy at depth. Reinhart ${ }^{19}$ obtained comparable corrosion rate data for 1010 carbon steel exposed at the surface of the sea and at a depth of 6,000 feet. For 7178-T6 aluminum alloy, it was $8.2 \mathrm{mpy}$ at the surface (estimated from Figure 36), compared to $3.65 \mathrm{mpy}$ at depth. Since aluminum alloys corrode by the pitting rather than by the uniform surface corrosion, the prediction of performance by the extrapolation of corrosion rates calculated from weight loss data alone is not entirely satisfactory. 


\section{FINDINGS AND CONCLUSIONS}

1. The effect of marine fouling on corrosion of carbon steel and aluminum alloy panels exposed at the surface of the open sea was not definitely established by the experimental methods used in this current study because the initially sterile control specimens became contaminated with bacteria after immersion in the sea.

2. Bacterial slime growth and its metabolic products apparently play a significant role in accelerating corrosion on the deep-ocean floor.

3. The corrosion rates of exposed test panels placed in the sea at the surface were greater than for identical panels which were exposed on the seafloor in 6,000 feet of water.

4. The corrosion rates of both carbon steel and aluminum alloy panels approach constancy after 9 months of exposure in the sea. As shown in Figures 35 and 36 it can be expected that these corrosion rates will continue at this lower rate after extended period of exposure.

\section{FUTURE PLANS}

Additional test specimens of 1010 carbon steel and 7178-T6 aluminum alloy have been placed on a STU (STU I-6) to determine the effects of biological organisms on corrosion. The STU was emplaced on the ocean floor at a depth of 6,000 feet of water on 3 December 1969 during the second quarter of FY 70 .

If further controlled studies of marine corrosion processes (biological, chemical, and physical) are undertaken, microtechniques should be developed to study the various chemical reactions which occur at the microlayer immediately above the surface of test specimens - for example, measure the oxygen concentration, $\mathrm{pH}, \mathrm{H}_{2} \mathrm{~S}$ concentration, temperature, current velocity, etc. at the metal-seawater interface. The effects of metabolic products and byproducts of fouling organisms on corrosion should also be investigated. The control panels should be carefully protected from biological factors by specially designed sterile test chambers which would keep the test specimens free of fouling attachment including microorganisms but would continuously expose them to other parameters of the seawater environment. Such a study could be undertaken in the laboratory by pumping filtered seawater through a sterile test chamber sealed with membrane filters and containing test panels. The cylinder should first be tightly fitted inside a plastic tube so that seawater is pumped through the membrane filters. By using this method, the fresh 
seawater flowing through the sterile chamber, can be analyzed periodically for dissolved oxygen concentration, salinity, $\mathrm{pH}$, and for bacteria. The current velocity flowing through the chamber can be controlled. Identical test panels should be placed just outside the sterile test chamber so that marine microorganisms (slime film) will become attached to the panel. In addition, replicate test panels should be exposed in the open sea so that marine fouling organisms will become attached to the panels. The corrosion due to biological effects can then be determined by comparing the corrosion rates of the exposed panels to those of control panels.

\section{REFERENCES}

1. F. L. LaQue. "Behavior of metals and alloys in sea water," in Corrosion handbook, edited by H. H. Uhlig. New York, Wiley, 1948, pp. 394-400. (Whole article pp. 383-430).

2. Naval Civil Engineering Laboratory. Technical Report R-504: Corrosion of materials in hydrospace, by F. M. Reinhart. Port Hueneme, Calif., Dec. 1966. (AD 644473)

3. Woods Hole Oceanographic Institution. Marine fouling and its prevention; prepared for Bureau of Ships, Navy Department. Annapolis, Md., United States Naval Institute, 1952. (Contribution no. 580).

4. F. L. LaQue and W. F. Clapp. "Relationships between corrosion and fouling of copper-nickel alloys in sea water," Electrochemical Society, Trans., vol. 87, 1945, pp. 103-125. (Preprint no. 87-15).

5. Naval Civil Engineering Laboratory. Technical Report R-612: Plastic film coatings for protection from marine fouling and corrosion, by J. S. Muraoka. Port Hueneme, Calif., Feb. 1969. (AD 682938)

6. C. V. Brouillette. "Corrosion rates in Port Hueneme harbor," Corrosion, vol. 14, no. 8, Aug. 1958, pp. 16-21 (352t-356t).

7. R. L. Starkey. "The general physiology of the sulfate-reducing bacteria in relation to corrosion," Producers Monthly, vol. 22, no. 8, June 1958, pp. 12-30.

8. A. K. Tiller and G. H. Booth. "Anaerobic corrosion of aluminum by sulphate-reducing bacteria," Corrosion Science, vol. 8, no. 7, July 1968, pp. 549-555. 
9. R. F. Hadley. "Corrosion by micro-organisms in aqueous and soil environments," in Corrosion handbook, edited by H. H. Uhlig. New York, Wiley, 1948, pp. 466-481.

10. National Research Council. Prevention of Deterioration Center. PDC Search No. 63-025; PDL-48074: Bibliography on microbial corrosion of metals, compiled by R. W. H. Lee. Washington, D. C., July 1963. (AD 601247)

11. Arthur D. Little, Inc. Unnumbered report: The relationship between bacterial slime films and the initial stage of marine corrosion and fouling. Preliminary bacteriological and electron micrographic investigations of aluminum and copper, by P. Himmelfarb, et al. Cambridge, Mass., Mar. 1964.

12. R. Y. Morita and C. E. ZoBell. "Occurrence of bacteria in pelagic sediments collected during the Mid-Pacific Expedition," Deep-Sea Research, vol. 3, no. 1, Oct. 1955, pp. 66-73.

13. F. L. LaQue, and H. R. Copson, eds. Corrosion resistance of metals and alloys, 2d ed. New York, Reinhold, 1963.

14. U. R. Evans. An introduction to metallic corrosion. London, Edward Arnold and Co., 1948.

15. Naval Civil Engineering Laboratory. Technical Report R-428: Deepocean biodeterioration of materials - Part III. Three years at 5,300 feet, by J. S. Muraoka. Port Hueneme, Calif., Feb. 1966. (AD 631078)

16. - Technical Report R-456: Deep-ocean biodeterioration of materials_Part IV. One year at 6,800 feet, by J. S. Muraoka. Port Hueneme, Calif., June 1966. (AD 636412)

17. - Technical Report R-525: Deep-ocean biodeterioration of materials-Part VI. One year at 2,370 feet, by J. S. Muraoka, Port Hueneme, Calif., May 1967. (AD 651124)

18. - Technical Report R-563: Bacteria at oceanographic stations off Southern California-Population distribution in relation of depth, by J. S. Muraoka. Port Hueneme, Calif., Jan. 1968. (AD 664954)

19. - Technical Note N-900: Corrosion of materials in hydrospace, Pt 1. Irons, steels, cast irons, and steel products, by F. M. Reinhart. Port Hueneme, Calif., July 1967. (AD 818171L) 


\section{DISTRIBUTION LIST}

$\begin{array}{cccl}\begin{array}{c}\text { SNDL } \\ \text { Code }\end{array} & \begin{array}{c}\text { No. of } \\ \text { Activities }\end{array} & \begin{array}{c}\text { Total } \\ \text { Copies }\end{array} & \\ \text { FKAIC } & 1 & 20 & \text { Defense Documentation Center } \\ \text { FKNI } & 1 & 10 & \text { Naval Facilities Engineering Command } \\ \text { FKN5 } & 9 & 13 & \text { NAVFAC Engineering Field Divisions } \\ \text { FA25 } & 1 & 9 & \text { Public Works Centers } \\ - & 14 & 14 & \begin{array}{l}\text { Public Works Center } \\ \text { RDT\&E Liaison Officers at NAVFAC } \\ \text { Engineering Field Divisions and } \\ \text { Construction Battalion Centers } \\ \text { NCEL Special Distribution List No. 5 } \\ \text { for Government Activities interested in } \\ \text { reports on Deterioration Control }\end{array}\end{array}$





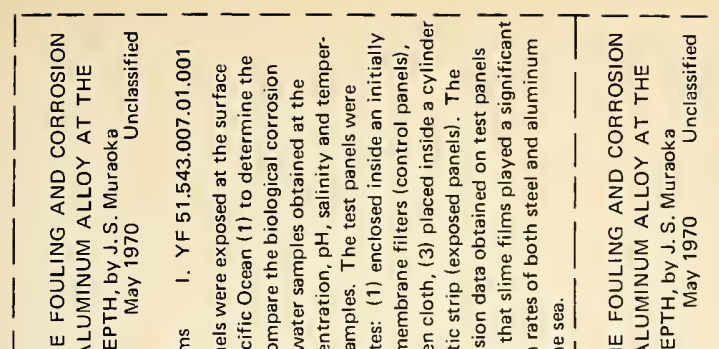
岂专㟔

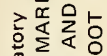

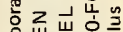
음

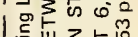
要岩施 |言䞸选呈 ш 2 胥은 넝 떵 可山㟧品

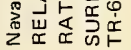

\section{|}

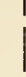

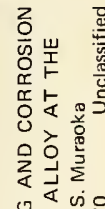 \\ ¿ \\ 方方 \\ ○坟 \\ 柁占 \\ 岂㟧 \\ 文造呈占

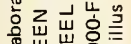 贯㟧

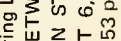 要造}

宗言品只

岳岕交

를은벙

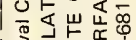

勇㟧造品 致

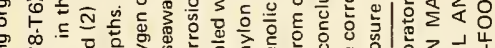

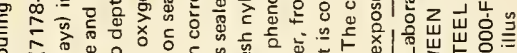

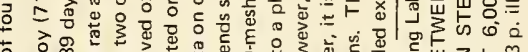

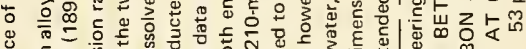

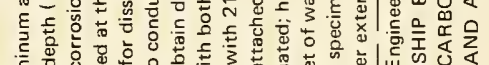

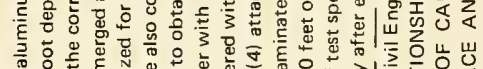

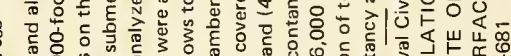

离 $\leq$ 둥

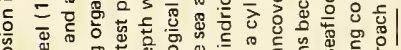

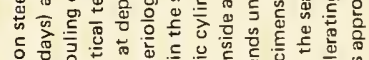

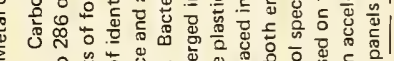

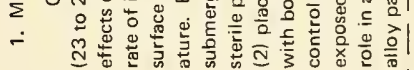

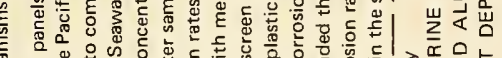

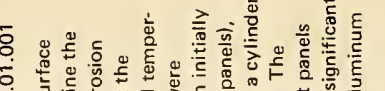

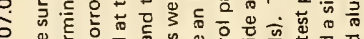

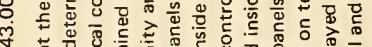

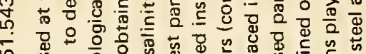
万人

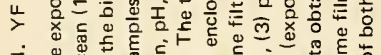

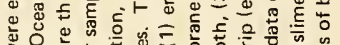

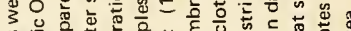
点步它

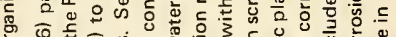

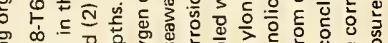

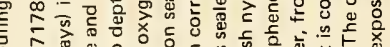

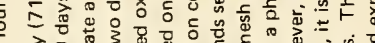

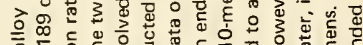

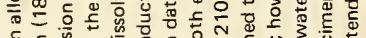

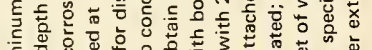

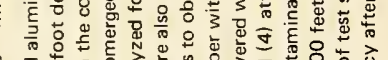
둥등

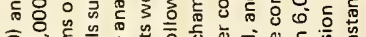

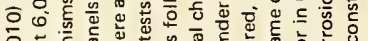
흘

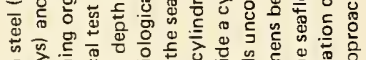

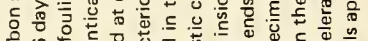

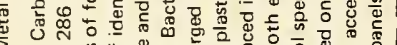

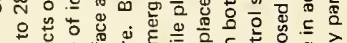

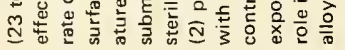




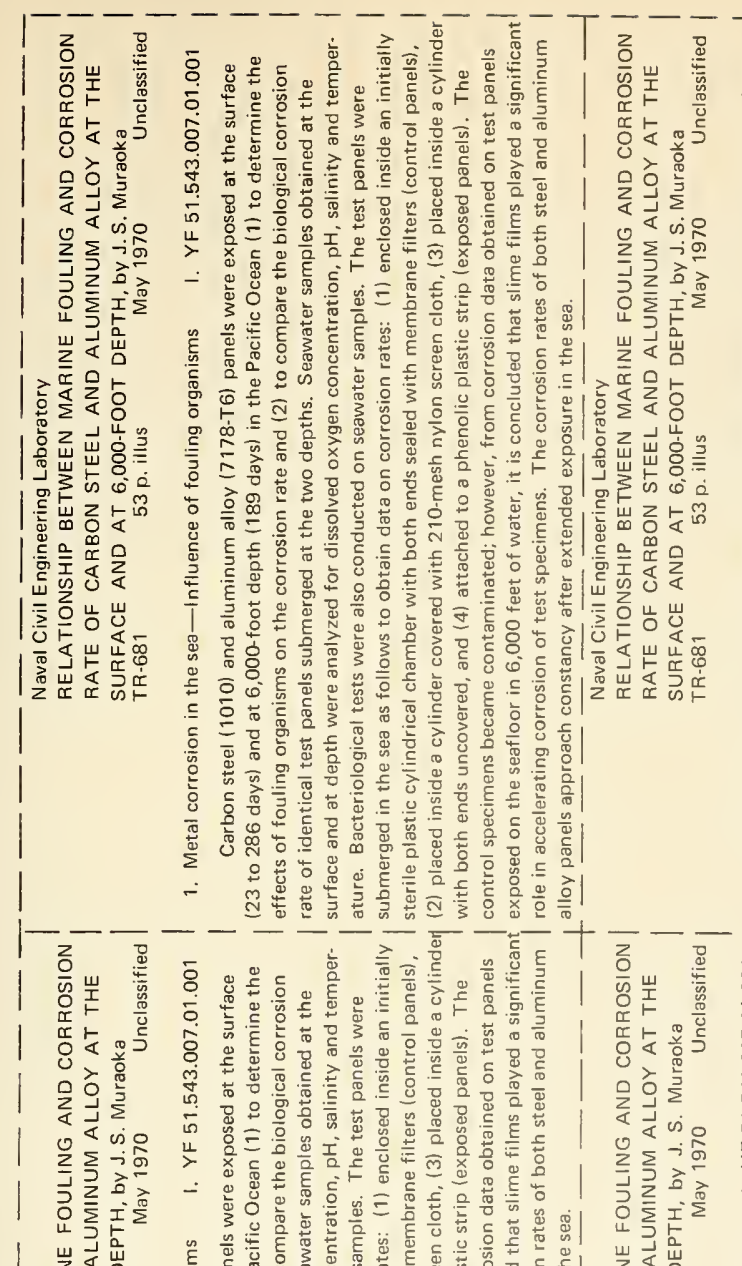

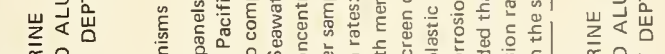

$>$ 兵员占

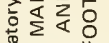

|

总

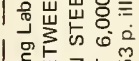

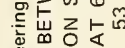

|

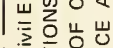

|

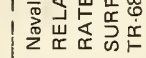

के

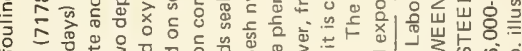

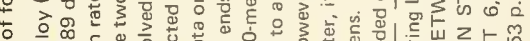

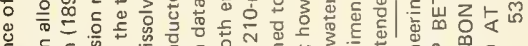

至

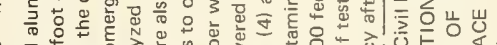

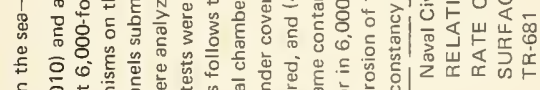

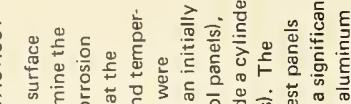

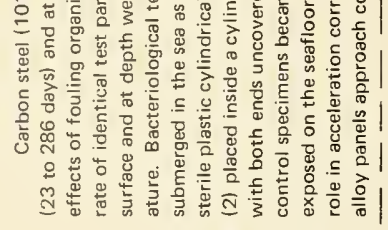

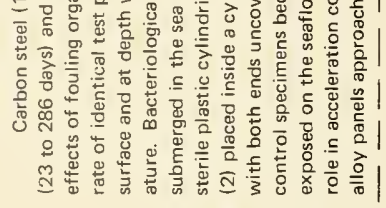

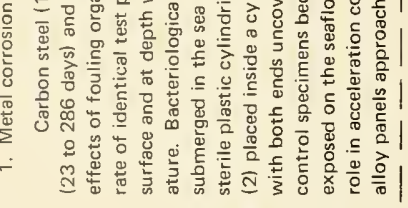

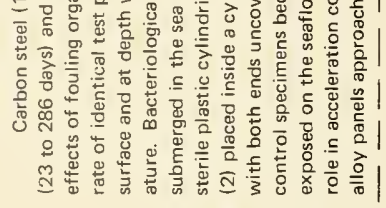

ᄃ

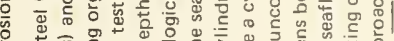

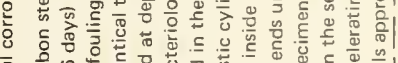

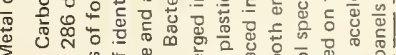

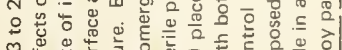

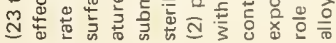

ᄃ

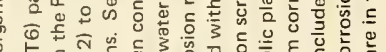

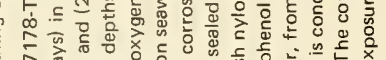

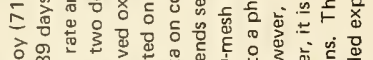

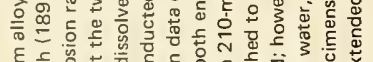

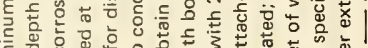
है एँ О은 



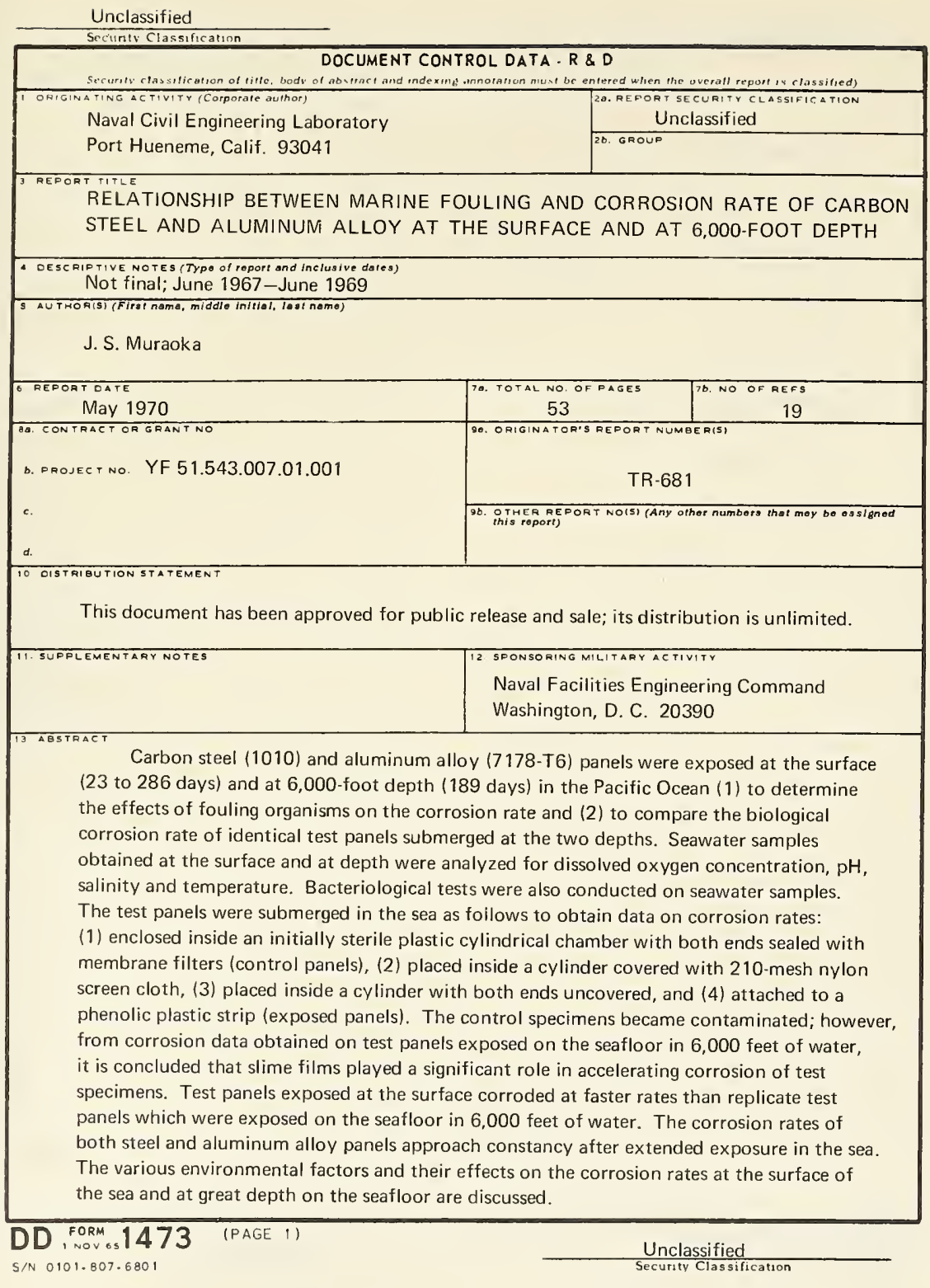


